Prepared in cooperation with the Muskingum Watershed Conservancy District and Richland County

\title{
Development of a Flood-Inundation Map Library and Precipitation-Runoff Modeling for the Clear Fork Mohican River in and near Bellville, Ohio
}

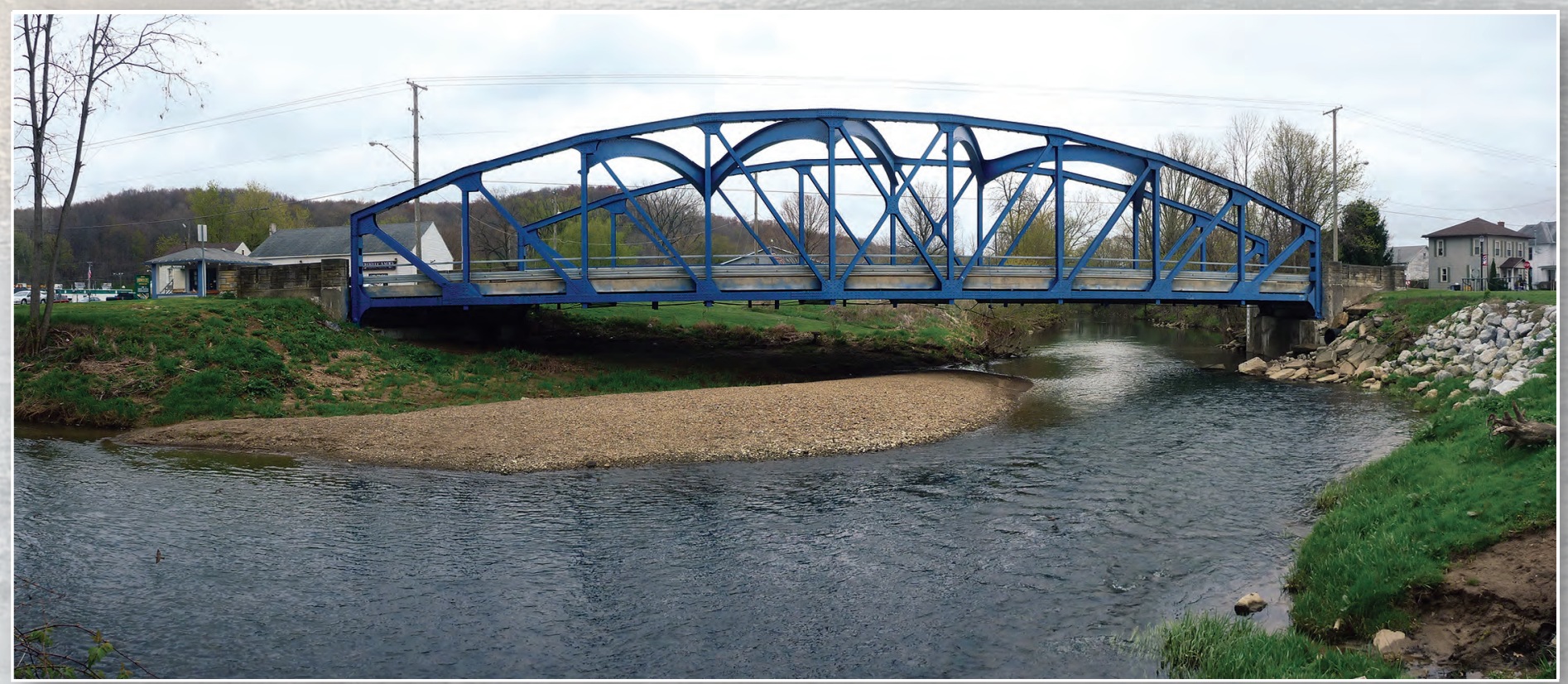

Scientific Investigations Report 2019-5017 
Cover photograph. View looking downstream at State Route 13/97 (North High Street) bridge over Clear Fork Mohican River at Bellville, Ohio. Photograph by U.S. Geological Survey, April 2015. 


\section{Development of a Flood-Inundation Map Library and Precipitation-Runoff Modeling for the Clear Fork Mohican River in and near Bellville, Ohio}

By Chad J. Ostheimer and Carrie A. Huitger

Prepared in cooperation with the Muskingum Watershed Conservancy District and Richland County

Scientific Investigations Report 2019-5017 


\title{
U.S. Department of the Interior \\ DAVID BERNHARDT, Secretary
}

\author{
U.S. Geological Survey \\ James F. Reilly II, Director
}

U.S. Geological Survey, Reston, Virginia: 2019

For more information on the USGS - the Federal source for science about the Earth, its natural and living resources, natural hazards, and the environment-visit https://www.usgs.gov or call 1-888-ASK-USGS.

For an overview of USGS information products, including maps, imagery, and publications,

visit https://store.usgs.gov.

Any use of trade, firm, or product names is for descriptive purposes only and does not imply endorsement by the U.S. Government.

Although this information product, for the most part, is in the public domain, it also may contain copyrighted materials as noted in the text. Permission to reproduce copyrighted items must be secured from the copyright owner.

Suggested citation:

Ostheimer, C.J., and Huitger, C.A., 2019, Development of a flood-inundation map library and precipitation-runoff modeling for the Clear Fork Mohican River in and near Bellville, Ohio: U.S. Geological Survey Scientific Investigations Report 2019-5017, 34 p., including 1 appendix, https://doi.org/10.3133/sir20195017.

ISSN 2328-0328 (online) 


\section{Contents}

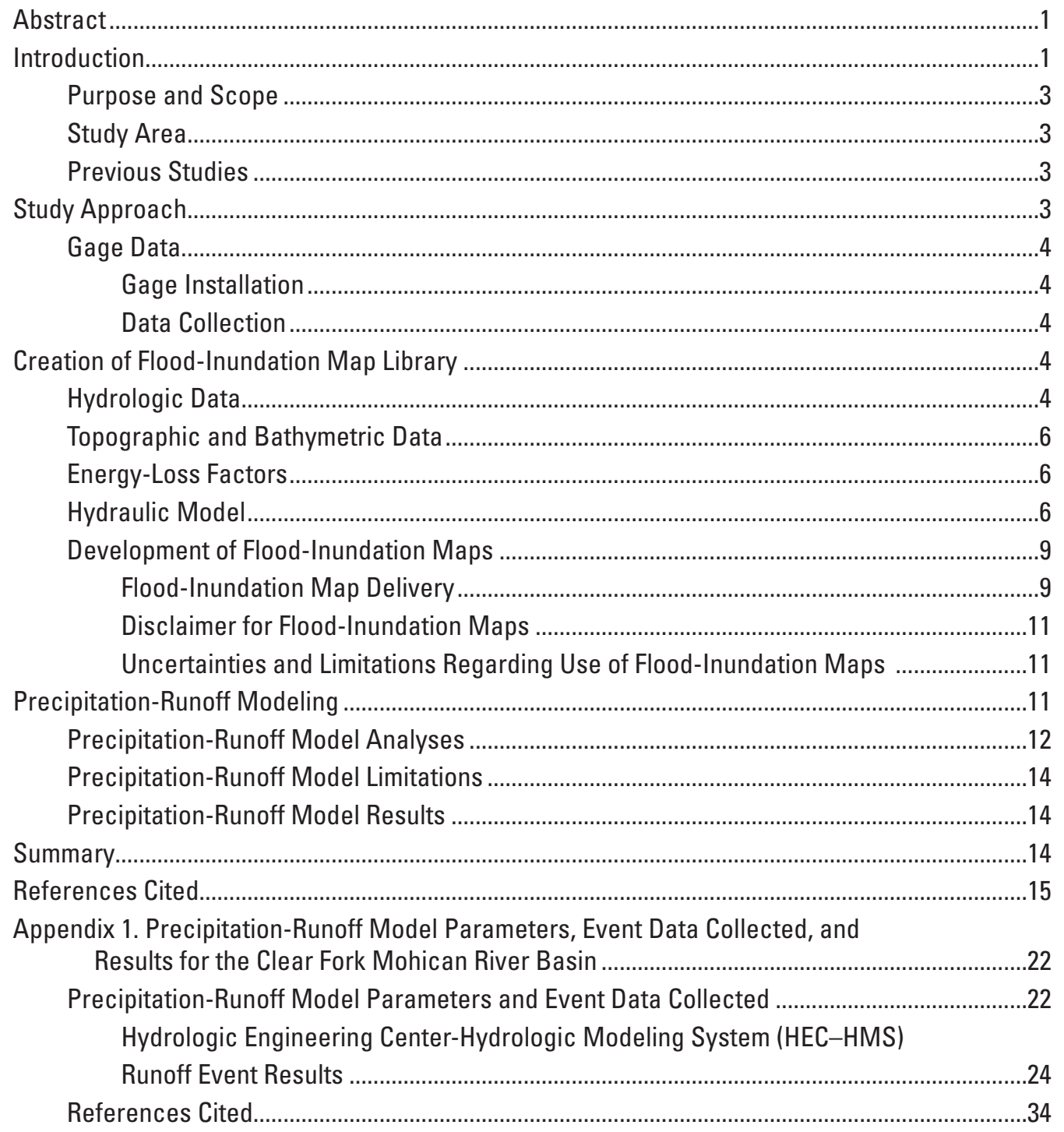

\section{Figures}

1. The Clear Fork Mohican River Basin, selected tributaries, and monitoring locations.

2. Flood-inundation map for the Clear Fork Mohican River at Bellville, Ohio, corresponding to a stage of 17.0 feet at the U.S. Geological Survey streamgage (station number 03131982). 


\section{Tables}

1. U.S. Geological Survey data collection information for Clear Fork Mohican River Basin.

2. Stages, corresponding discharges, and water-surface elevations at the Clear Fork Mohican River at Bellville, Ohio, streamgage (U.S. Geological Survey station number 03131982) used in the hydraulic model of the Clear Fork Mohican River at Bellville, Ohio

3. Comparisons of published National Geodetic Survey benchmark coordinates and elevations to those surveyed by the U.S. Geological Survey.

4. Calibration of model to target water-surface elevations at the streamgage Clear Fork Mohican River at Bellville, Ohio (station number 03131982) ....

5. Calibration of model to recorded water-surface elevations at selected locations along the Clear Fork Mohican River for 16 measured events.

6. Summary data from the U.S. Geological Survey streamgage Clear Fork Mohican River at Bellville, Ohio (station number 03131982), including the observed data from selected dates, estimates obtained using the HEC-HMS precipitation-runoff model, and the model performance statistics.

\section{Conversion Factors}

U.S. customary units to International System of Units

\begin{tabular}{lcl}
\hline \multicolumn{1}{c}{ Multiply } & By & \multicolumn{1}{c}{ To obtain } \\
\hline foot $(\mathrm{ft})$ & Length & \\
mile $(\mathrm{mi})$ & 0.3048 & meter $(\mathrm{m})$ \\
& 1.609 & kilometer $(\mathrm{km})$ \\
\hline square $\mathrm{mile}\left(\mathrm{mi}^{2}\right)$ & Area & \\
\hline & 2.590 & square kilometer $\left(\mathrm{km}^{2}\right)$ \\
\hline cubic foot per second $\left(\mathrm{ft}^{3} / \mathrm{s}\right)$ & Flow rate & \\
\hline
\end{tabular}

Temperature in degrees Celsius $\left({ }^{\circ} \mathrm{C}\right)$ may be converted to degrees Fahrenheit $\left({ }^{\circ} \mathrm{F}\right)$ as follows:

$$
{ }^{\circ} \mathrm{F}=\left(1.8 \times{ }^{\circ} \mathrm{C}\right)+32
$$

Temperature in degrees Fahrenheit $\left({ }^{\circ} \mathrm{F}\right)$ may be converted to degrees Celsius $\left({ }^{\circ} \mathrm{C}\right)$ as follows:

$$
{ }^{\circ} \mathrm{C}=\left({ }^{\circ} \mathrm{F}-32\right) / 1.8 \text {. }
$$

\section{Datum}

Vertical coordinate information is referenced to (1) stage, the height above an arbitrary datum established at a streamgage and (2) elevation, the height above the North American Vertical Datum of 1988 (NAVD 88).

Horizontal coordinate information is referenced to the North American Datum of 1983 (NAD 83). 


\title{
Development of a Flood-Inundation Map Library and Precipitation-Runoff Modeling for the Clear Fork Mohican River in and near Bellville, Ohio
}

\author{
By Chad J. Ostheimer and Carrie A. Huitger
}

\section{Abstract}

The U.S. Geological Survey (USGS), in cooperation with the Muskingum Watershed Conservancy District, led hydrologic and hydraulic analyses within the Clear Fork Mohican River Basin in and near Bellville, Ohio. The analyses included the development of digital flood-inundation maps for an approximately 2.5-mile reach of the Clear Fork Mohican River and the development of a precipitation-runoff model for a portion of the Clear Fork Mohican River Basin.

Data collection for the study involved the installation and operation of 2 streamgages (Clear Fork Mohican River at Bellville, Ohio, and Cedar Fork above Bellville, Ohio); 1 lake-level gage (Clear Fork Reservoir near Lexington, Ohio); 2 precipitation gages (Clear Fork Reservoir near Lexington, Ohio, and Rain Gage at Cedar Fork above Bellville, Ohio); and 12 submersible pressure transducers on Clear Fork Mohican River and 4 of its tributaries. Data collection also included field surveys of hydraulic structures and channel cross sections.

Flood profiles were computed for the 2.5-mile reach of the Clear Fork Mohican River by means of a one-dimensional step-backwater model. The model was calibrated to 16 measured events and to a portion (stages 9 to 11 feet) of the current stage-streamflow relation at the USGS streamgage Clear Fork Mohican River at Bellville, Ohio, and to stage recorded at a submersible pressure transducer site near the downstream study limit. After calibration the step-backwater model was used to compute nine flood profiles for stages ranging from 9 to 17 feet. The flood profiles were then used in combination with a digital elevation model to delineate the area that would be inundated at each stage.

A precipitation-runoff model was developed and calibrated using data from the streamgage, precipitation gage, and 11 submersible pressure transducers. The modeling included data during 10 runoff events that were used for model calibration and validation, with focus on 6 events. The Nash-Sutcliffe model efficiency coefficients for six peak streamflow events ranged from 0.459 to 0.851 .
The models produced by this study can be used to assess possible flood mitigation options and define flood hazard areas that could contribute to the protection of life and property. The availability of flood-inundation maps, internet information from USGS streamgages, and forecasted stages from the National Weather Service could provide emergency management personnel and residents with information on forecasting floods, appropriate flood response activities, and post-flood recovery efforts.

\section{Introduction}

Low-lying areas adjacent to the Clear Fork Mohican River near Bellville, Ohio, are subject to periodic flooding. Bellville, Ohio, is just downstream from the confluence of Cedar Fork (drainage area of 47.7 square miles $\left[\mathrm{mi}^{2}\right]$ ) and Clear Fork Mohican River (drainage area of $64.4 \mathrm{mi}^{2}$ ), making the city of Bellville subject to flooding from two similar sized basins (fig. 1).

The estimated population of Bellville is about 2,000 (U.S. Census Bureau, 2018). The Ohio Emergency Management Agency estimates that 68 flood-insurance policies are currently (2016) in effect in Bellville, with a total annual premium of $\$ 52,784$ (Steve Ferryman, Ohio Emergency Management Agency, written commun., 2016). As of August 2016, the insured losses paid for Bellville totaled \$903,929 (Steve Ferryman, Ohio Emergency Management Agency, written commun., 2016).

The most recent flooding was in 1959 and 1987. The 1959 flood left Bellville completely isolated for a time (Cross and Brooks, 1959). The July 1987 flood had a peak-flood stage of approximately 16.8 feet (ft) at the Main Street bridge in Bellville (Mayo and Mangus, 1989) and damages were estimated to be more than $\$ 5$ million (Mayo and Mangus, 1989). For reference, major flood stage for Bellville as designated 


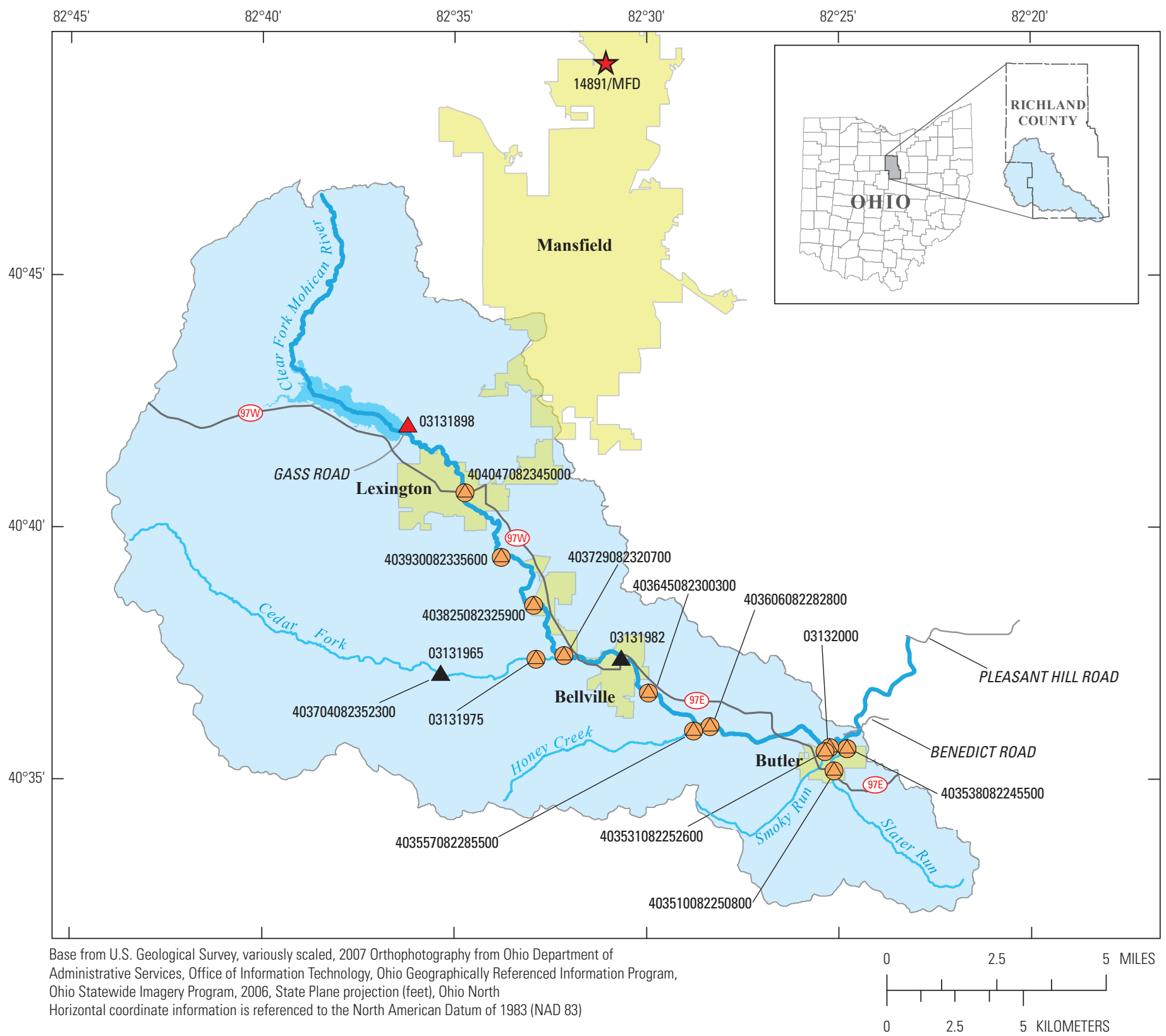

\section{EXPLANATION}

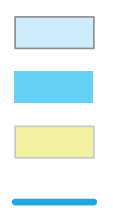

Clear Fork Mohican River Basin
Clear Fork Reservoir
Corporate limits
Clear Fork Mohican River

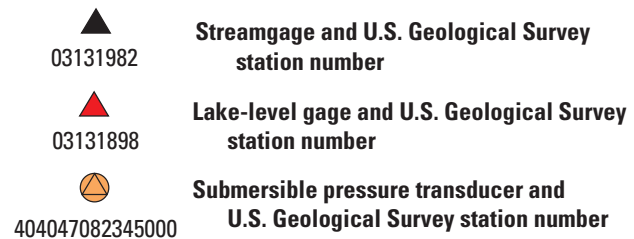

14891/MFD Mansfield Lahm Municipal Airport weather station and station number

(975) State Highway marker

Figure 1. The Clear Fork Mohican River Basin, selected tributaries, and monitoring locations. 
by the National Weather Service (NWS) is $15.5 \mathrm{ft}$ (National Weather Service, 2018a). To help officials plan and respond to future flooding in the Bellville area, the U.S. Geological Survey (USGS) and Muskingum Watershed Conservancy District initiated a cooperative study to better understand the hydrology and hydraulics of a selected portion of the Clear Fork Mohican River and its tributaries. The hydraulic portion of this study is part of a larger USGS modeling effort to update the Federal Emergency Management Agency (FEMA) Flood Insurance Study (FIS) for Richland County for the Clear Fork Mohican River.

\section{Purpose and Scope}

The purpose of this report is to describe the methods and results of hydrologic and hydraulic analyses of the Clear Fork Mohican River near Bellville, Ohio. The hydraulic analysis includes the development of flood-inundation maps for selected stages at the USGS streamgage Clear Fork Mohican River at Bellville, Ohio (station number 03131982; hereafter referred to as the "Bellville streamgage"). The hydrologic analysis includes the development of a precipitation-runoff model for a portion of the Clear Fork Mohican River Basin. The results of this study can be used to assess possible flood mitigation options and define flood hazard areas that could contribute to the protection of life and property.

\section{Study Area}

The Clear Fork Mohican River Basin (fig. 1) is in northcentral Ohio approximately 50 miles northeast of Columbus, Ohio. The hydrologic portion of this study focused on a 153- $\mathrm{mi}^{2}$ basin area encompassing the headwaters of Clear Fork Mohican River (near Mansfield, Ohio) downstream to where the river intersects Benedict Road (about 1 mile northeast of Butler, Ohio). The hydraulic model portion of this study focused on a 2.5-mile reach of the Clear Fork Mohican River within and near the corporate limits of Bellville.

The basin drains a largely rural area that is mostly forested and agricultural land. The Clear Fork Reservoir (997 acres), near the headwaters of Clear Fork Mohican River (approximately 2 miles northwest of Lexington, Ohio), is used as a drinking water supply to Mansfield, Ohio. The reservoir water level is passively controlled by a fixed-elevation outflow weir and, therefore, does not provide meaningful flood protection (Federal Emergency Management Agency, 2011). Because the primary function of the reservoir is for water supply, the reservoir has little to no flood control except during periods of drought when the water level drops below the level of the outflow weir providing limited flood storage capacity.
The reach limits of the flood-inundation maps in this study are within the limits of a larger FIS reach that is being concurrently studied by the USGS. The FIS limits are from approximately $700 \mathrm{ft}$ downstream from Benedict Road in Butler, Ohio (river station 16,605 ft), to approximately $100 \mathrm{ft}$ upstream from Glass Road near Lexington, Ohio (river station $114,793 \mathrm{ft}$ ); a reach length of 18.6 miles. However, the lower limit of the flood-inundation mapping effort (river station $50,096 \mathrm{ft}$ ) is approximately 6.3 miles upstream from the FIS lower limit, and the upper limit is just downstream from State Route 97 (river station 63,296).

\section{Previous Studies}

The effective FEMA FIS for Richland County was published on April 4, 2011 and includes the reach of the Clear Fork Mohican River through Bellville (Federal Emergency Management Agency, 2011). In the FIS, portions of the Clear Fork Mohican River were studied by detailed methods in 1988 and 1991 using hydrology completed in 1965. Flood-inundation areas were re-delineated using light detection and ranging (lidar) data collected in 2005 by the Richland County Regional Planning Commission (2018). In early 2018, the USGS submitted a revised FIS that included updated hydrology and hydraulic modeling for the Clear Fork Mohican River and new hydrology and hydraulic modeling for Cedar Fork. The revised FIS utilized contemporary data sources and updated elevation data.

\section{Study Approach}

The hydraulic portion of this study produced flood profiles for 1-ft stage increments from 9 to $17 \mathrm{ft}$ as referenced to the Bellville streamgage (station number 03131982). These profiles were developed using the U.S. Army Corps of Engineers (USACE) Hydrologic Engineering Center's River Analysis System (HEC-RAS) version 4.1 (USACE, 2010a, b, c). The HEC-RAS is a one-dimensional, steady-flow, step-backwater model. The streamflows used as inputs for each profile were computed from the stage-streamflow rating at the Bellville streamgage.

A precipitation-runoff model was developed using the USACE Hydrologic Engineering Center's Hydrologic Modeling System (HEC-HMS) version 4.2 (USACE, 2016). The HECHMS is a model designed to simulate the complete hydrologic processes of dendritic watershed systems. The model used precipitation, streamflow, and water-level data collected in the Clear Fork Mohican River Basin to help calibrate and validate the model. Water-level data were collected at seven locations on the Clear Fork Mohican River and on four tributaries, namely Cedar Fork, Honey Creek, Smoky Run, and Slater Run (fig. 1). The water-level data were needed to help calibrate the timing of precipitation and runoff in the model. 
Flood-Inundation Map Library and Precipitation-Runoff Modeling for the Clear Fork Mohican River, Bellville, Ohio

\section{Gage Data}

As part of this project, the USGS installed, operated, and collected streamflow, lake-level, stream-level, and precipitation data at several locations in the Clear Fork Mohican River Basin (fig. 1, table 1). These data were used in the calibration of the hydraulic (HEC-RAS) and precipitation-runoff (HEC-HMS) model.

\section{Gage Installation}

A lake-level gage (station number 03131898) and a colocated precipitation gage were installed at the outflow of the Clear Fork Reservoir in May of 2015. The Bellville streamgage (station number 03131982) was installed at the Main Street Bridge in Bellville in July 2015. In July 2017, after discussions with the cooperator, a streamgage (station number 03131965) and a colocated precipitation gage (station number 403704082352300) were installed on Cedar Fork upstream and west of Bellville (fig. 1).

Twelve submersible pressure transducers were installed along the Clear Fork Mohican River and four of its tributaries (Cedar Fork, Honey Creek, Smoky Run, and Slater Run) (fig. 1). During the project, the equipment was lost for Slater Run at Resort Drive at Butler, Ohio (station number 403538082245500). To continue data collection on Slater Run, the Resort Drive site was discontinued and replaced with Slater Run at Butler, Ohio (station number 403510082250800), approximately 0.6 mile upstream. The submersible pressure transducers were operated between April 2015 and March of 2018. Stream-level data from the submersible pressure transducers were corrected for changing barometric pressure, which was measured using barometric pressure sensors located at the Bellville streamgage and at the Clear Fork Reservoir precipitation gage.

\section{Data Collection}

Stage, streamflow, and precipitation were recorded every 15 minutes and telemetered hourly to USGS systems via a Geostationary Operational Environmental Satellite (GOES) transmitter. Each site was also equipped with Automated Local Evaluation in Real Time (ALERT) telemetry and a voice modem that was programmed to call local emergency phone numbers at designated stream levels or at a specified rate of increase. A detailed description of the methods used for data collection by the USGS is in Rantz and others (1982). Data from the submersible pressure transducers were downloaded onsite during periodic field visits. All the data are available on the internet through the USGS National Water Information System (NWIS; U.S. Geological Survey, 2018a-q).

In addition to stream-level data and precipitation data collected by the USGS, precipitation and air temperature data were obtained from the NWS station Mansfield Lahm Municipal Airport (station number 14891/MFD; National Oceanic and Atmospheric Administration, 2018), which is approximately 14 miles north of Bellville (fig. 1) in an adjacent drainage basin. The precipitation data from the NWS station were used only to determine whether there was snow on the ground prior to a runoff event (the cold-weather initial surface conditions); however, the temperature data were used in the precipitation-runoff model. Initial surface conditions for coldweather events were no snow accumulation on the ground, and any modeled precipitation during the events used air temperature to determine whether the precipitation fell as rain or snow.

\section{Creation of Flood-Inundation Map Library}

The USGS has standardized procedures for creating flood-inundation maps (U.S. Geological Survey, 2018r) so that the process followed and the products produced are similar across the USGS. Tasks specific to development of the flood-inundation maps were (1) collection of topographic and bathymetric data for selected cross sections and geometric data for structures along the study reach; (2) estimation of energyloss factors (roughness coefficients) in the stream channel and flood plain; (3) computation of flood profiles using the USACE HEC-RAS computer program (USACE, 2010a, b, c); (4) production of estimated flood-inundation maps at several river stages using the USACE Hydrologic Engineering Center's GeoRiver Analysis System (HEC-GeoRAS) computer program (USACE, 2009) and a geographic information system (GIS) computer program called ArcGIS (Esri, 2015); and (5) preparation of the maps, both as shapefile polygons that depict the areal extent of flood inundation and as depth grids that provide the depth of floodwaters, for display on the USGS flood-inundation mapping application.

\section{Hydrologic Data}

Peak streamflows used in the HEC-RAS simulations (table 2) were computed from stage-streamflow rating 3.0, effective January 2017 at the Bellville streamgage (station number 03131982) for $1-\mathrm{ft}$ increments of stage from 9 to $17 \mathrm{ft}$. Rating 3.0 was only available up to a stage of $11.0 \mathrm{ft}$. As a result, the calibrated HEC-RAS model that was developed for this study was used to estimate streamflows for stages 12 to $17 \mathrm{ft}$.

The target stages selected for analysis were based on the range of stages at the Bellville streamgage (station number 03131982) that the NWS has labeled as the gage's "action stage" (10 ft), the "major flood stage" (15.5 ft) (National Weather Service, 2018a), and the highest historical peak (16.8 ft in 1987) (Mayo and Mangus, 1989). The NWS defines the "action stage" as the stage that, when reached by a rising stream, requires the NWS or a partner to take some type of mitigation action in preparation for possible significant 
Table 1. U.S. Geological Survey data collection information for Clear Fork Mohican River Basin.

[Site locations are shown in figure 1. USGS, U.S. Geological Survey; $\mathrm{mi}^{2}$, square mile; ft, foot; NAVD 88, North American Vertical Datum of 1988; current, 2018; n/a, not applicable]

\begin{tabular}{|c|c|c|c|c|c|c|}
\hline Site name & $\begin{array}{c}\text { USGS } \\
\text { station number }\end{array}$ & $\begin{array}{c}\text { Drainage } \\
\text { area } \\
\left(\mathrm{mi}^{2}\right)\end{array}$ & Latitude & Longitude & Period of record & $\begin{array}{c}\text { Maximum stage (ft) } \\
\text { (elevation [ft, NAVD 88]), } \\
\text { date }\end{array}$ \\
\hline \multicolumn{7}{|c|}{ Streamgages } \\
\hline Cedar Fork above Bellville, Ohio & 03131965 & 35.8 & $40^{\circ} 37^{\prime} 04^{\prime \prime}$ & $82^{\circ} 35^{\prime} 23^{\prime \prime}$ & July 2017 to current & $10.55(1,164.88)$, November 2017 \\
\hline Clear Fork Mohican River at Bellville, Ohio & 03131982 & 115 & $40^{\circ} 37^{\prime} 24^{\prime \prime}$ & $82^{\circ} 30^{\prime} 40^{\prime \prime}$ & July 2015 to current & 16.8 (1,126.9), July $1987^{1}$ \\
\hline \multicolumn{7}{|c|}{ Lake-level gage } \\
\hline Clear Fork Reservoir near Lexington, Ohio & 03131898 & 33.7 & $40^{\circ} 41^{\prime} 59^{\prime \prime}$ & $82^{\circ} 36^{\prime} 22^{\prime \prime}$ & May 2015 to current & $1,203.31(1,203.31)$, January 2017 \\
\hline \multicolumn{7}{|c|}{ Precipitation gages } \\
\hline Clear Fork Reservoir near Lexington, Ohio & 03131898 & $\mathrm{n} / \mathrm{a}$ & $40^{\circ} 41^{\prime} 59^{\prime \prime}$ & $82^{\circ} 36^{\prime} 22^{\prime \prime}$ & May 2015 to current & $\mathrm{n} / \mathrm{a}$ \\
\hline $\begin{array}{l}\text { Rain Gage at Cedar Fork above } \\
\text { Bellville, Ohio }\end{array}$ & 403704082352300 & $\mathrm{n} / \mathrm{a}$ & $40^{\circ} 37^{\prime} 04^{\prime \prime}$ & $82^{\circ} 35^{\prime} 23^{\prime \prime}$ & July 2017 to current & $\mathrm{n} / \mathrm{a}$ \\
\hline \multicolumn{7}{|c|}{ Submersible pressure transducers } \\
\hline $\begin{array}{l}\text { Clear Fork Mohican River at } \\
\text { Lexington, Ohio }\end{array}$ & 404047082345000 & 51.4 & $40^{\circ} 40^{\prime} 47^{\prime \prime}$ & $82^{\circ} 34^{\prime} 50^{\prime \prime}$ & April 2015 to March 2018 & $6.21(1,164.33)$, November 2017 \\
\hline $\begin{array}{l}\text { Clear Fork Mohican River below } \\
\text { Lexington, Ohio }\end{array}$ & 403930082335600 & 56.3 & $40^{\circ} 39^{\prime} 30^{\prime \prime}$ & $82^{\circ} 33^{\prime} 56^{\prime \prime}$ & April 2015 to March 2018 & 4.97 (1,155.48), November 2017 \\
\hline $\begin{array}{l}\text { Clear Fork Mohican River at Ritter Road } \\
\text { above Bellville, Ohio }\end{array}$ & 403825082325900 & 62 & $40^{\circ} 38^{\prime} 25^{\prime \prime}$ & $82^{\circ} 32^{\prime} 59^{\prime \prime}$ & April 2015 to March 2018 & 3.41 (1,143.34), November 2017 \\
\hline $\begin{array}{l}\text { Clear Fork Mohican River above } \\
\text { Bellville, Ohio }\end{array}$ & 403729082320700 & 64.4 & $40^{\circ} 37^{\prime} 29^{\prime \prime}$ & $82^{\circ} 32^{\prime} 07^{\prime \prime}$ & April 2015 to March 2018 & $9.53(1,131.40)$, July 2017 \\
\hline $\begin{array}{l}\text { Clear Fork Mohican River below } \\
\text { Bellville, Ohio }\end{array}$ & 403645082300300 & 116 & $40^{\circ} 36^{\prime} 45^{\prime \prime}$ & $82^{\circ} 30^{\prime} 03^{\prime \prime}$ & May 2015 to March 2018 & 6.82 (1,110.62), July 2017 \\
\hline $\begin{array}{l}\text { Clear Fork Mohican River above Butler, } \\
\text { Ohio }\end{array}$ & 403606082282800 & 128 & $40^{\circ} 36^{\prime} 06^{\prime \prime}$ & $82^{\circ} 28^{\prime} 28^{\prime \prime}$ & May 2015 to March 2018 & $6.87(1,093.75)$, November 2017 \\
\hline Clear Fork at Butler, Ohio & 03132000 & 136 & $40^{\circ} 35^{\prime} 31^{\prime \prime}$ & $82^{\circ} 25^{\prime} 26^{\prime \prime}$ & $\begin{array}{l}\text { May } 1945 \text { to September } 1975^{2} \\
\text { May } 2015 \text { to March } 2018\end{array}$ & $10.87(1,067.50)$, July $1987^{3}$ \\
\hline $\begin{array}{l}\text { Cedar Fork Mohican River near } \\
\text { Bellville, Ohio }\end{array}$ & 03131975 & 46.5 & $40^{\circ} 37^{\prime} 25^{\prime \prime}$ & $82^{\circ} 32^{\prime} 57^{\prime \prime}$ & April 2015 to March 2018 & 8.88 (1,138.33), July 2017 \\
\hline Honey Creek near Butler, Ohio & 403557082285500 & 9.79 & $40^{\circ} 35^{\prime} 57^{\prime \prime}$ & $82^{\circ} 28^{\prime} 55^{\prime \prime}$ & May 2015 to March 2018 & 4.79 (1,096.72), November 2017 \\
\hline Smoky Run at Butler, Ohio & 403531082252600 & 6.49 & $40^{\circ} 35^{\prime} 31^{\prime \prime}$ & $82^{\circ} 25^{\prime} 26^{\prime \prime}$ & May 2015 to March 2018 & 3.99 (1,065.84), November 2017 \\
\hline Slater Run at Butler, Ohio & 403510082250800 & 8.32 & $40^{\circ} 35^{\prime} 10^{\prime \prime}$ & $82^{\circ} 25^{\prime} 08^{\prime \prime}$ & May 2015 to September 2015 & 4.76 (1,057.84), July 2015 \\
\hline Slater Run at Resort Drive at Butler, Ohio ${ }^{3}$ & 403538082245500 & 8.51 & $40^{\circ} 35^{\prime} 38^{\prime \prime}$ & $82^{\circ} 24^{\prime} 55^{\prime \prime}$ & January 2016 to March 2018 & $4.86(1,075.48)$, November 2017 \\
\hline
\end{tabular}

${ }^{1}$ The July 1987 flood event was documented in a report by Mayo and Mangus (1989).

${ }^{2}$ The submersible pressure transducer was located at a discontinued streamgage site.

${ }^{3}$ Data collection for Slater Run was moved from this site to the Slater Run at Butler, Ohio, site after the equipment was lost. 
Table 2. Stages, corresponding discharges, and watersurface elevations at the Clear Fork Mohican River at Bellville, Ohio, streamgage (U.S. Geological Survey station number 03131982) used in the hydraulic model of the Clear Fork Mohican River at Bellville, Ohio.

[ft, foot; $\mathrm{ft}^{3} / \mathrm{s}$, cubic foot per second; NAVD 88, North American Vertical Datum of 1988]

\begin{tabular}{rcc}
\hline $\begin{array}{c}\text { Stage } \\
(\mathbf{f t})^{\mathbf{1}}\end{array}$ & $\begin{array}{c}\text { Streamflow } \\
\left(\mathbf{f t}^{3} / \mathbf{s}\right)\end{array}$ & $\begin{array}{c}\text { Elevation } \\
\text { (ft, NAVD 88) }\end{array}$ \\
\hline 9 & 3,070 & $1,119.08$ \\
10 & 3,950 & $1,120.08$ \\
11 & 5,000 & $1,121.08$ \\
${ }^{2} 12$ & ${ }^{2} 8,520$ & $1,122.08$ \\
${ }^{2} 13$ & ${ }^{2} 10,700$ & $1,123.08$ \\
${ }^{2} 14$ & ${ }^{2} 13,000$ & $1,124.08$ \\
${ }^{2} 15$ & ${ }^{2} 15,400$ & $1,125.08$ \\
${ }^{2} 16$ & ${ }^{2} 18,200$ & $1,126.08$ \\
${ }^{2} 17$ & ${ }^{2} 21,300$ & $1,127.08$ \\
\hline
\end{tabular}

${ }^{1}$ Flood profiles are 1-foot increments of stage, referenced to the gage datum of the streamgage Clear Fork Mohican River at Bellville, Ohio (station number 03131982).

${ }^{2}$ Indicates stage and streamflow estimates higher than rating 3.0 for the streamgage Clear Fork Mohican River at Bellville, Ohio. Streamflow estimates for these stages are based on a theoretical rating.

hydrologic activity (National Weather Service, 2018b). The NWS defines the major flood stage as a stage that involves "extensive inundation of structures and roads" and causes "significant evacuations of people and/or property to higher elevations" (National Weather Service, 2018c).

\section{Topographic and Bathymetric Data}

Cross-section elevation data were obtained from a digital elevation model (DEM) that was provided to the USGS by Richland County, Ohio, and derived from light detection and ranging (lidar) data that were collected during April 2005. The original lidar data have horizontal resolution $(5 \mathrm{ft})$ that meets National Map Accuracy Standards and vertical accuracy of plus or minus $1.0 \mathrm{ft}$ at a 95 -percent confidence level for the "open terrain" land-cover category (root-mean-square error of $0.5 \mathrm{ft}$ ). The DEM data were converted into 2 -ft contours by Aerocon Photogrammetric Service, Inc. under contract with Richland County, Ohio. By using the USACE HEC-GeoRAS (USACE, 2009), elevation data were extracted from the DEM for 56 cross sections for use in the HEC-RAS model. HEC-GeoRAS is a set of procedures, tools, and utilities for processing geospatial data in ArcGIS (Esri, 2015).

To supplement the cross-section data extracted from the DEM with bathymetric data and to measure the geometry of hydraulic structures that have the potential to affect watersurface elevations during floods, USGS field crews surveyed channel cross sections at four locations and measured the geometry of five bridges and one low-head dam. A differential global positioning system with real-time kinematic technology was used to determine horizontal coordinates and elevations at each surveyed cross section and structure. The accuracy of these surveys was checked by comparing the elevations determined by the real-time kinematic differential global positioning system at 11 benchmarks to their National Geodetic Survey published elevations, and these checks had a rootmean-square error of $0.09 \mathrm{ft}$ (table 3 ).

The DEM-derived cross sections were colocated with the locations of the in-channel field-surveyed cross sections where available. In those cases, in-channel data were directly merged with the DEM data. The bathymetry for the DEM-derived cross sections that did not have field-surveyed channel elevations were estimated by linearly interpolating between the closest field-surveyed cross sections.

\section{Energy-Loss Factors}

Hydraulic analyses require the estimation of energy losses exerted by a channel on flow. These energy losses are quantified by the Manning's roughness coefficient (" $n$ " value). Initial (precalibration) $n$ values were selected on the basis of field observations and high-resolution aerial photographs. As part of the calibration process, initial $n$ values were adjusted until the differences between simulated and rated water-surface elevations were minimized at the Bellville streamgage and at the submersible pressure transducer site on Clear Fork Mohican River below Bellville, Ohio (station number 403645082300300). The final $n$ values ranged from 0.038 to 0.044 for the main channel and from 0.03 to 0.10 for the overbank areas modeled in this analysis.

\section{Hydraulic Model}

The HEC-RAS analysis for this study was done using the steady-state flow computation option. Steady-state flow data consisted of flow regime, boundary conditions, and streamflow estimates. The model used a subcritical flow regime for all simulations. The downstream boundary condition (normal depth) was a water-surface slope of 0.0026 foot per foot, as calculated from field surveys near Benedict Road. Streamflows for target stream levels (discussed in the "Hydrologic Data" section) were computed from rating 3.0 for the Bellville streamgage (station number 03131982).

The hydraulic baseline was referenced to feet upstream from Pleasant Hill Road to match the 2011 FIS work. Peak streamflows were then routed upstream to the flood-inundation mapping reach lower study limit (fig. 2), resulting in a 6.3-mile convergence reach. The HEC-RAS model was calibrated to stages 9 to $11 \mathrm{ft}$ of the stage-streamflow rating 3.0 at the Bellville streamgage (station number 03131982, at river station 56,283 ) and to 16 measured events at both the Bellville streamgage and a submersible pressure transducer at Clear Fork Mohican River below Bellville, Ohio (station 
Table 3. Comparisons of published National Geodetic Survey benchmark coordinates and elevations to those surveyed by the U.S. Geological Survey.

[All data are shown in feet. Ohio State Plane (Ohio North) Coordinate System. NGS, National Geodetic Survey; NAD 83, North American Datum of 1983; NAVD 88, North American Vertical Datum of 1988; USGS, U.S. Geological Survey; n/a, not applicable]

\begin{tabular}{|c|c|c|c|c|c|c|c|c|c|c|}
\hline $\begin{array}{c}\text { NGS } \\
\text { benchmark } \\
\text { name }\end{array}$ & $\begin{array}{l}\text { Permanent } \\
\text { identifier } \\
\text { (PID) }\end{array}$ & $\begin{array}{l}\text { Published } \\
\text { NGS } \\
\text { northing } \\
\text { (NAD 83) }\end{array}$ & $\begin{array}{l}\text { Published } \\
\text { NGS } \\
\text { easting } \\
\text { (NAD 83) }\end{array}$ & $\begin{array}{l}\text { Published } \\
\text { NGS } \\
\text { elevation } \\
\text { (NAVD 88) }\end{array}$ & $\begin{array}{l}\text { Surveyed by } \\
\text { USGS } \\
\text { northing } \\
\text { (NAD 83) }\end{array}$ & $\begin{array}{l}\text { Surveyed by } \\
\text { USGS } \\
\text { easting } \\
\text { (NAD 83) }\end{array}$ & $\begin{array}{l}\text { Surveyed by } \\
\text { USGS } \\
\text { elevation } \\
\text { (NAVD 88) } \\
\end{array}$ & $\begin{array}{c}\text { Delta } \\
\text { northing } \\
\text { (NAD 83) }\end{array}$ & $\begin{array}{c}\text { Delta } \\
\text { easting } \\
\text { (NAD 83) }\end{array}$ & $\begin{array}{c}\text { Delta } \\
\text { elevation } \\
\text { (NAVD 88) }\end{array}$ \\
\hline X 251 & KZ0078 & $\mathrm{n} / \mathrm{a}$ & $\mathrm{n} / \mathrm{a}$ & $1,088.14$ & $\mathrm{n} / \mathrm{a}$ & $\mathrm{n} / \mathrm{a}$ & $1,088.08$ & $\mathrm{n} / \mathrm{a}$ & $\mathrm{n} / \mathrm{a}$ & 0.06 \\
\hline Z 251 & KZ0312 & $1,994,351.33$ & $344,038.71$ & $1,072.29$ & $1,994,351.30$ & $344,038.70$ & $1,072.24$ & 0.03 & 0.01 & 0.05 \\
\hline C 252 & KZ0316 & $\mathrm{n} / \mathrm{a}$ & $\mathrm{n} / \mathrm{a}$ & $1,051.42$ & $\mathrm{n} / \mathrm{a}$ & $\mathrm{n} / \mathrm{a}$ & $1,051.33$ & $\mathrm{n} / \mathrm{a}$ & $\mathrm{n} / \mathrm{a}$ & 0.09 \\
\hline E 28 & KZ1113 & $\mathrm{n} / \mathrm{a}$ & $\mathrm{n} / \mathrm{a}$ & $1,125.50$ & $\mathrm{n} / \mathrm{a}$ & $\mathrm{n} / \mathrm{a}$ & $1,125.39$ & $\mathrm{n} / \mathrm{a}$ & $\mathrm{n} / \mathrm{a}$ & 0.11 \\
\hline L 269 & KZ1116 & $\mathrm{n} / \mathrm{a}$ & $\mathrm{n} / \mathrm{a}$ & $1,133.46$ & $\mathrm{n} / \mathrm{a}$ & $\mathrm{n} / \mathrm{a}$ & $1,133.38$ & $\mathrm{n} / \mathrm{a}$ & $\mathrm{n} / \mathrm{a}$ & 0.08 \\
\hline Н 268 & KZ1126 & $\mathrm{n} / \mathrm{a}$ & $\mathrm{n} / \mathrm{a}$ & $1,176.10$ & $\mathrm{n} / \mathrm{a}$ & $\mathrm{n} / \mathrm{a}$ & $1,175.99$ & $\mathrm{n} / \mathrm{a}$ & $\mathrm{n} / \mathrm{a}$ & 0.11 \\
\hline $\mathrm{J} 28$ & KZ1132 & $\mathrm{n} / \mathrm{a}$ & $\mathrm{n} / \mathrm{a}$ & $1,285.63$ & $\mathrm{n} / \mathrm{a}$ & $\mathrm{n} / \mathrm{a}$ & $1,285.68$ & $\mathrm{n} / \mathrm{a}$ & $\mathrm{n} / \mathrm{a}$ & -0.05 \\
\hline S 251 & KZ1216 & $\mathrm{n} / \mathrm{a}$ & $\mathrm{n} / \mathrm{a}$ & $1,173.99$ & $\mathrm{n} / \mathrm{a}$ & $\mathrm{n} / \mathrm{a}$ & $1,173.99$ & $\mathrm{n} / \mathrm{a}$ & $\mathrm{n} / \mathrm{a}$ & 0.00 \\
\hline R 270 & KZ1276 & $\mathrm{n} / \mathrm{a}$ & $\mathrm{n} / \mathrm{a}$ & $1,169.26$ & $\mathrm{n} / \mathrm{a}$ & $\mathrm{n} / \mathrm{a}$ & $1,169.20$ & $\mathrm{n} / \mathrm{a}$ & $\mathrm{n} / \mathrm{a}$ & 0.06 \\
\hline Q 270 & KZ1277 & $\mathrm{n} / \mathrm{a}$ & $\mathrm{n} / \mathrm{a}$ & $1,136.56$ & $\mathrm{n} / \mathrm{a}$ & $\mathrm{n} / \mathrm{a}$ & $1,136.42$ & $\mathrm{n} / \mathrm{a}$ & $\mathrm{n} / \mathrm{a}$ & 0.14 \\
\hline E 272 & KZ1304 & $\mathrm{n} / \mathrm{a}$ & $\mathrm{n} / \mathrm{a}$ & $1,168.91$ & $\mathrm{n} / \mathrm{a}$ & $\mathrm{n} / \mathrm{a}$ & $1,168.80$ & $\mathrm{n} / \mathrm{a}$ & $\mathrm{n} / \mathrm{a}$ & 0.11 \\
\hline
\end{tabular}



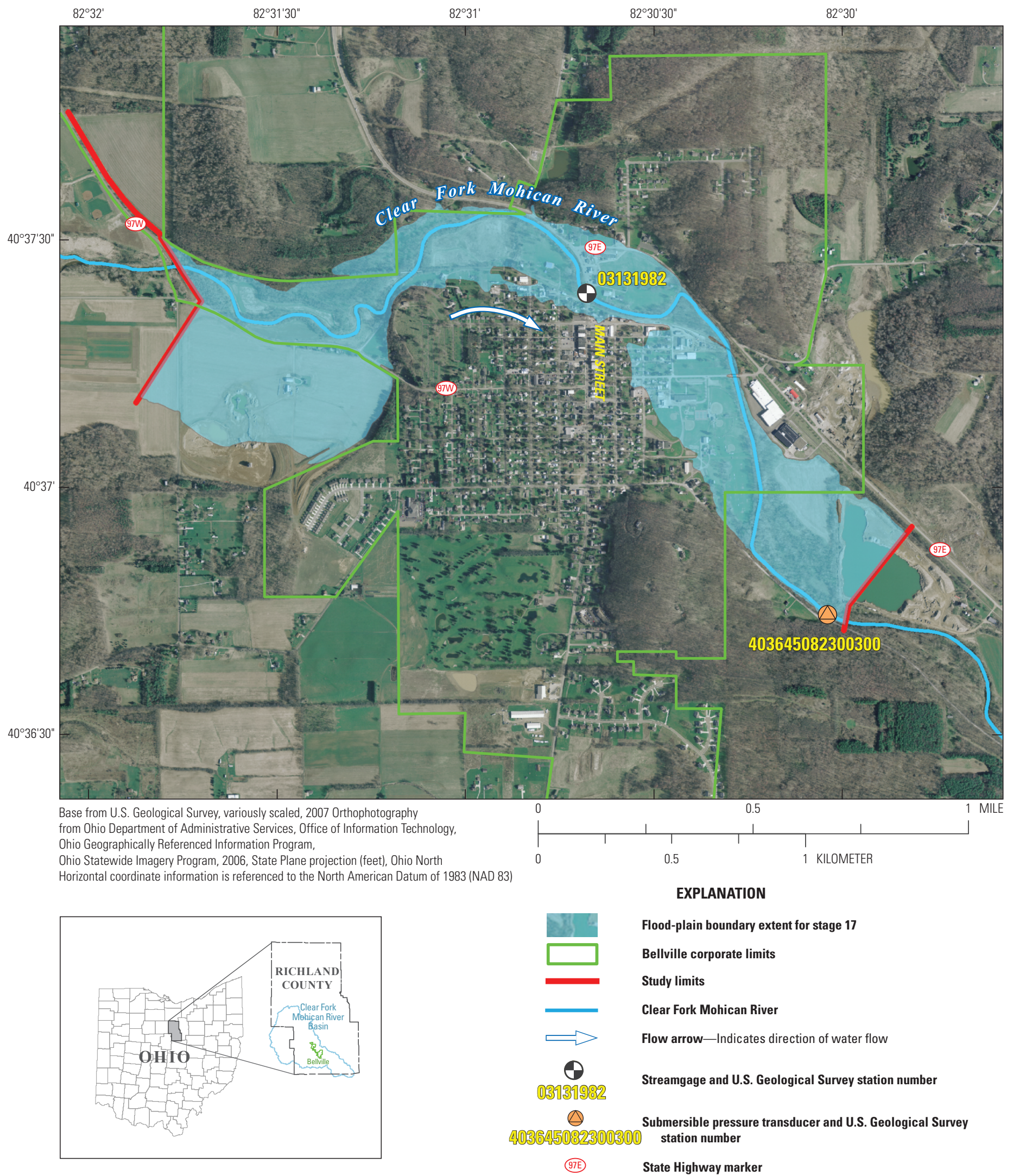

Figure 2. Flood-inundation map for the Clear Fork Mohican River at Bellville, Ohio, corresponding to a stage of 17.0 feet at the U.S. Geological Survey streamgage (station number 03131982). 
number 403645082300300, near the downstream study limit at river station 50,048). The model was calibrated by adjusting Manning's $n$ values and bridge contraction/expansion coefficients until the results of the hydraulic computations closely agreed with the target water-surface elevations for modeled streamflows.

Absolute differences between rating 3.0 and simulated water-surface elevations for stages 9 to $11 \mathrm{ft}$ at the Bellville streamgage were equal to or less than $0.05 \mathrm{ft}$ (table 4 ). Absolute differences between observed and simulated water-surface elevations for the 16 measured events recorded at the Bellville streamgage were equal to or less than $0.05 \mathrm{ft}$ (table 5). The root-mean-square error for the 16 measured events at the Bellville streamgage was $0.03 \mathrm{ft}$. The differences between recorded and simulated water-surface elevations for the measured events at the submersible pressure transducer, when the pressure transducer was not clogged by debris, ranged from -0.15 to $0.15 \mathrm{ft}$ (table 5). The root-mean-square error for all the non-clogged measured events was $0.08 \mathrm{ft}$. After the HEC-RAS model was calibrated, flood profiles for each of the target water levels $(1-\mathrm{ft}$ increments from 9 to $17 \mathrm{ft}$ at the Bellville streamgage) were generated.

\section{Development of Flood-Inundation Maps}

Flood-inundation maps were created in a GIS for the target water levels by combining flood-profile data with the Richland County DEM (described in "Topographic and Bathymetric Data" section). Initial flood-inundation boundaries were developed for each simulated profile by use of HEC-GeoRAS software (USACE, 2009). Flood-inundation boundaries and depth grids for the inundated areas were modified in ArcMap (Esri, 2015), as required, to ensure hydraulically reasonable transitions of the flood boundaries between modeled cross sections. The datasets used in this study are available through a data release at https://doi. org/10.5066/P95NMIDF (Ostheimer and Huitger, 2019).

Any inundated areas that were disconnected from the main channel were checked for connections with the main river, such as culverts that go under roadways. Where such connections existed, the mapped inundated areas were kept in their respective flood maps; otherwise, the disconnected inundated areas were deleted. The flood-inundation areas were overlain on high-resolution, georeferenced aerial photographs of the study area. The flood-inundation map corresponding to stage $17 \mathrm{ft}$ (the highest simulated water-surface profile) at the Bellville streamgage (station 03131982) is shown in figure 2.

\section{Flood-Inundation Map Delivery}

A Flood Inundation Mapping Science (FIMS) website (U.S. Geological Survey, 2018r) was established to serve USGS flood-inundation study information to the public.

The FIMS website has a mapping application that can display detailed information on flood extents and depths for modeled areas. The FIMS website contains a link to the USGS NWIS website, which displays the most recent stage and streamflow data at USGS streamgages. A second link on the FIMS website points to the NWS Advanced Hydrologic Prediction Service (AHPS) website where the user can obtain information on forecasted peak stage and flood-inundation study information (National Weather Service, 2018a).

Table 4. Calibration of model to target water-surface elevations at the streamgage Clear Fork Mohican River at Bellville, Ohio (station number 03131982).

[ft, foot; NAVD 88, North American Vertical Datum of 1988]

\begin{tabular}{cccc}
\hline $\begin{array}{c}\text { Target } \\
\text { water-surface } \\
\text { stage } \\
\text { (ft) }\end{array}$ & $\begin{array}{c}\text { Target } \\
\text { water-surface } \\
\text { elevation } \\
\text { (ft, NAVD 88) }\end{array}$ & $\begin{array}{c}\text { Modeled } \\
\text { water-surface } \\
\text { elevation } \\
\text { (ft, NAVD 88) }\end{array}$ & $\begin{array}{c}\text { Difference } \\
\text { in elevation } \\
\text { (ft) }\end{array}$ \\
\hline 9.00 & $1,119.08$ & $1,119.09$ & 0.01 \\
10.00 & $1,120.08$ & $1,120.04$ & -0.04 \\
11.00 & $1,121.08$ & $1,121.03$ & -0.05 \\
12.00 & $1,122.08$ & $1,122.08$ & ${ }^{1} 0.00$ \\
${ }^{1} 13.00$ & $1,123.08$ & $1,123.09$ & ${ }^{1} 0.01$ \\
${ }^{1} 14.00$ & $1,124.08$ & $1,124.09$ & ${ }^{1} 0.01$ \\
${ }^{1} 15.00$ & $1,125.08$ & $1,125.09$ & ${ }^{1} 0.01$ \\
${ }^{1} 16.00$ & $1,126.08$ & $1,126.09$ & ${ }^{1} 0.01$ \\
${ }^{1} 17.00$ & $1,127.08$ & $1,127.10$ & ${ }^{1} 0.02$ \\
\hline
\end{tabular}

${ }^{1}$ Indicates stage and streamflow estimates higher than rating 3.0 for the streamgage Clear Fork Mohican River at Bellville, Ohio. 
Table 5. Calibration of model to recorded water-surface elevations at selected locations along the Clear Fork Mohican River for 16 measured events.

[ft, foot; NAVD 88, North American Vertical Datum of 1988; USGS, U.S. Geological Survey; n/a, not applicable]

\begin{tabular}{|c|c|c|c|c|}
\hline Event date & $\begin{array}{c}\text { Recorded } \\
\text { water-surface } \\
\text { stage } \\
\text { (ft) }\end{array}$ & $\begin{array}{c}\text { Recorded } \\
\text { water-surface } \\
\text { elevation } \\
\text { (ft, NAVD 88) }\end{array}$ & $\begin{array}{c}\text { Modeled } \\
\text { water-surface } \\
\text { elevation } \\
\text { (ft, NAVD 88) }\end{array}$ & $\begin{array}{c}\text { Difference } \\
\text { in elevation } \\
\text { (ft) }\end{array}$ \\
\hline \multicolumn{5}{|c|}{$\begin{array}{l}\text { Cross section 150,408 (at submersible pressure transducer site, Clear Fork Mohican River below Bellville, Ohio, } \\
\text { USGS station number } 403645082300300 \text { ) }\end{array}$} \\
\hline June 16, 2015 & $\mathrm{n} / \mathrm{a}$ & $1,109.05$ & $1,109.08$ & 0.03 \\
\hline December 27, 2015 & $\mathrm{n} / \mathrm{a}$ & $1,109.40$ & $1,109.49$ & 0.09 \\
\hline February 24, 2016 & $\mathrm{n} / \mathrm{a}$ & $1,108.20$ & $1,108.13$ & -0.07 \\
\hline April 11, 2016 & $\mathrm{n} / \mathrm{a}$ & $1,109.14$ & $1,109.21$ & 0.07 \\
\hline January 12, 2017 & $\mathrm{n} / \mathrm{a}$ & $1,109.68$ & $1,110.04$ & ${ }^{2} 0.36$ \\
\hline February 7, 2017 & $\mathrm{n} / \mathrm{a}$ & $1,108.14$ & $1,108.06$ & -0.08 \\
\hline July 10, 2017 & $\mathrm{n} / \mathrm{a}$ & $1,108.18$ & $1,108.03$ & -0.15 \\
\hline July 13, 2017 & $\mathrm{n} / \mathrm{a}$ & $1,110.62$ & $1,110.66$ & -0.04 \\
\hline November 6, 2017 & $\mathrm{n} / \mathrm{a}$ & $1,109.03$ & $1,109.03$ & 0.00 \\
\hline November 19, 2017 & $\mathrm{n} / \mathrm{a}$ & $1,110.61$ & $1,110.61$ & 0.00 \\
\hline January 12, 2018 & $\mathrm{n} / \mathrm{a}$ & $1,108.52$ & $1,108.53$ & 0.01 \\
\hline February 16, 2018 & $\mathrm{n} / \mathrm{a}$ & $1,109.88$ & $1,110.45$ & ${ }^{3} 0.57$ \\
\hline February 19, 2018 & $\mathrm{n} / \mathrm{a}$ & $1,108.04$ & $1,108.19$ & 0.15 \\
\hline February 24, 2018 & $\mathrm{n} / \mathrm{a}$ & $1,108.00$ & $1,108.13$ & 0.13 \\
\hline February 25, 2018 & $\mathrm{n} / \mathrm{a}$ & $1,110.85$ & $1,110.89$ & 0.04 \\
\hline March 1, 2018 & $\mathrm{n} / \mathrm{a}$ & $1,108.88$ & $1,109.18$ & ${ }^{4} 0.30$ \\
\hline
\end{tabular}

Cross section 156,283 (at USGS streamgage Clear Fork Mohican River at Bellville, Ohio, station number 03131982)

\begin{tabular}{lrrrr}
\hline June 16, 2015 & 8.02 & $1,118.10$ & $1,118.13$ & 0.03 \\
\hline December 27, 2015 & 8.43 & $1,118.51$ & $1,118.54$ & 0.03 \\
\hline February 24, 2016 & 7.11 & $1,117.19$ & $1,117.20$ & 0.01 \\
\hline April 11, 2016 & 8.16 & $1,118.24$ & $1,118.26$ & 0.02 \\
\hline January 12, 2017 & 8.98 & $1,119.06$ & $1,119.07$ & 0.01 \\
\hline February 7, 2017 & 7.05 & $1,117.13$ & $1,117.13$ & 0.00 \\
\hline July 10, 2017 & 7.02 & $1,117.10$ & $1,117.09$ & -0.01 \\
\hline July 13, 2017 & 10.44 & $1,120.52$ & $1,120.48$ & -0.04 \\
\hline November 6, 2017 & 7.98 & $1,118.06$ & $1,118.09$ & 0.03 \\
\hline November 19, 2017 & 10.36 & $1,120.44$ & $1,120.39$ & -0.05 \\
\hline January 12, 2018 & 7.48 & $1,117.56$ & $1,117.58$ & 0.02 \\
\hline February 16, 2018 & 9.40 & $1,119.48$ & $1,119.45$ & -0.03 \\
\hline February 19, 2018 & 7.17 & $1,117.25$ & $1,117.26$ & 0.01 \\
\hline February 24, 2018 & 7.13 & $1,117.21$ & $1,117.20$ & -0.01 \\
\hline February 25, 2018 & 10.78 & $1,120.86$ & $1,120.81$ & -0.05 \\
\hline March 1, 2018 & 8.13 & $1,118.21$ & $1,118.23$ & 0.02 \\
\hline
\end{tabular}

${ }^{1}$ Cross-section identification numbers are referenced (in feet) to the longitudinal baseline used in the hydraulic model.

${ }^{2}$ Sometime before or during the January 2017 event, the submersible pressure transducer became clogged with silt and debris, likely causing an incorrect low reading.

${ }^{3}$ The submersible pressure transducer possibly was clogged before or during the February 16, 2018, event causing an incorrect low reading. The clog seems to have been temporary because the preceding and following events indicate good agreement.

${ }^{4}$ The submersible pressure transducer was noted as partially clogged during the data download on March 22, 2018. The pressure transducer likely became clogged after the February 25, 2018, event causing an incorrect low reading. 
The flood-inundation maps are displayed in sufficient detail so that preparations for flooding and decisions for emergency response can be made. In the maps, shaded areas represent inundation. As a note, a shaded building does not necessarily mean that the structure is submerged; rather, a shaded building may mean that bare-earth surfaces near the building are inundated.

\section{Disclaimer for Flood-Inundation Maps}

The flood-inundation maps should not be used for navigation, regulatory, permitting, or other legal purposes. The USGS provides these maps "as-is" for a quick reference, emergency planning tool but assumes no legal liability or responsibility resulting from the use of this information.

\section{Uncertainties and Limitations Regarding Use of Flood-Inundation Maps}

Although the flood-inundation maps represent the boundaries of inundated areas with a distinct line, some uncertainty is associated with these maps. The flood boundaries shown were estimated on the basis of water stages and streamflows at selected USGS streamgages. Water-surface elevations along the stream reaches were estimated by steadystate hydraulic modeling, assuming unobstructed flow, and using streamflows and hydrologic conditions anticipated at the USGS streamgage. The hydraulic model reflects the land-cover characteristics and any bridge, dam, levee, or other hydraulic structures existing as of March 2015. Unique meteorological factors (timing and distribution of precipitation) may cause actual streamflows along the modeled reach to vary from those assumed during a flood, which may lead to deviations in the water-surface elevations and inundation boundaries shown. Additional areas may be flooded due to unanticipated conditions such as changes in the streambed elevation or roughness, backwater into major tributaries along a main stem river, or backwater from debris or ice jams. The accuracy of the floodwater extent portrayed on these maps will vary with the accuracy of the DEM used to simulate the land surface.

If this series of flood-inundation maps is used in conjunction with NWS river forecasts, the user should be aware of additional uncertainties that may be inherent or factored into NWS forecast procedures. The NWS uses forecast models to estimate the quantity and timing of water flowing through selected stream reaches in the United States. These forecast models (1) estimate the amount of runoff generated by precipitation and snowmelt, (2) simulate the movement of floodwater as it proceeds downstream, and (3) predict the flow and stage (and water-surface elevation) for the stream at a given location (AHPS forecast point) throughout the forecast period (every 6 hours and 3 to 5 days out in many locations). For more information on AHPS forecasts, please see https://water. weather.gov/ahps/pcpn_and_river_forecasting.pdf. Additional uncertainties and limitations pertinent to this study are described elsewhere in this report.

\section{Precipitation-Runoff Modeling}

The precipitation-runoff model of the Clear Fork Mohican River Basin was developed using precipitation data collected in the basin and streamflow and water-level data collected on selected stream reaches. The modeling was done for future use to assess possible flood mitigation options. The USACE HEC-HMS model was prepared for a $153-\mathrm{mi}^{2}$ portion of the Clear Fork Mohican River Basin ending just downstream from Butler (at Benedict Road/Township Highway 349) in southwest Richland County (fig. 1). The model was constructed using the HEC Geospatial Hydrologic Modeling Extension (HECGeoHMS) version 10.0 (USACE, 2010d) for ArcGIS version 10.0 (Esri, 2015). The HEC-GeoHMS uses a DEM to delineate watershed boundaries and drainage paths and then transforms these into a hydrologic data structure that can be used in the HEC-HMS to model the watershed response to precipitation. The HEC-GeoHMS creates the HEC-HMS basin model and the background map file and computes physical watershed and stream characteristics. The contributing drainage area size at which a stream was defined (the stream network threshold) for this project is $1.5 \mathrm{mi}^{2}$. A $10-\mathrm{ft}$ DEM (a raster with $10 \mathrm{ft}$ by $10 \mathrm{ft}$ cells aggregated from the Ohio Geographically Referenced Information Program [2007] $2.5 \mathrm{ft}$ DEM) was used to define the watershed and its characteristics. The DEM was preprocessed following procedures listed in the HEC-GeoHMS User's Manual (USACE, 2010d).

The Arc Hydro tool (Esri, 2015) in ArcMap was used to develop a runoff-curve number (CN) (U.S. Department of Agriculture, 2004) grid based on the Natural Resources Conservation Service Soil Survey Geographic database (Soil Survey Staff, 2018) and land cover data from the 2011 National Land Cover Database (Homer and others, 2015). The 2011 National Land Cover Database has 20 classification categories that, for the purpose of $\mathrm{CN}$ assignment, were aggregated into the following 5 supersets of classification: water, low residential development, medium/high residential development, forest, and agriculture. The $\mathrm{CN}$ grid was used to calculate area weighted composite $\mathrm{CNs}$ for each of the 42 subbasins using a combination of land use and soil type characteristics.

Modeling was done with version 4.2 of the HEC-HMS (USACE, 2016). The HEC-HMS model is capable of simulating infiltration losses, runoff, channel routing, and base flow by means of a variety of methods. The model developed for the Clear Fork Mohican River Basin uses the Soil Conservation Service CN method (developed by the U.S. Department of Agriculture) to simulate runoff and the Muskingum-Cunge eight-point method for channel routing (USACE, 2016). Base flow was estimated using the recession method with an initial streamflow of 0.5 cubic foot per second $\left(\mathrm{ft}^{3} / \mathrm{s}\right)$, a recession constant of 0.5 , and base flow reset threshold type of ratio to peak, using a ratio of 0.15 . Initial abstraction values were intentionally left blank in the model input so that the HEC-HMS would automatically calculate the value as 0.2 times the potential maximum retention (which is calculated as a function of the $\mathrm{CN}$ ). 
Transformation of the excess precipitation to a runoff hydrograph was done by means of the Soil Conservation Service unit hydrograph method (USACE, 2016), which requires a peak streamflow and an estimation of basin lag time. Basin time of concentration and lag times were estimated using the HEC-GeoHMS extension in ArcGIS (Esri, 2015). The CN lag method was used to estimate the lag time for all 42 subbasins.

The HEC-HMS model constructed for the Clear Fork Mohican River Basin contains 20 reaches and 42 subbasins ranging in area from 0.049 to $16.6 \mathrm{mi}^{2}$. Muskingum-Cunge routing parameters such as reach length and energy slope were estimated from the DEM and DEM-derived drainage paths. The 8-point representation of the channel cross section was used in the model with 22 different cross sections. Crosssection geometries for reaches along the Clear Fork Mohican River and Cedar Fork reach were based on surveyed data. Cross-section geometries for other reaches and tributaries in the model were estimated on the basis of aerial photography from the Ohio Geographically Referenced Information Program (2018) and digital 2-ft contour data supplied by the Richland County Regional Planning Commission. Roughness coefficients for the channels and overbank areas were estimated from a limited number of field-based observations and from aerial photography. The aerial photography was obtained from the Ohio Geographically Referenced Information Program (2018) within the Ohio Office of Information Technology. Roughness coefficients used in the model for the channels ranged from 0.030 to 0.042 , and the overbank areas ranged from 0.038 to 0.10 .

In addition to stream-level and precipitation data collected by the USGS, precipitation and air temperature data were obtained from the NWS station Mansfield Lahm Municipal Airport (station number 14891/MFD; National Oceanic and Atmospheric Administration, 2018), which is approximately 14 miles north of Bellville in an adjacent drainage basin (fig. 1). The precipitation data from the NWS station were used only to determine whether there was snow on the ground prior to a runoff event (the cold-weather initial surface conditions); however, the temperature data were used in the precipitation-runoff model. Initial surface conditions for cold-weather events were no snow accumulation on the ground, and any modeled precipitation during the events used air temperature to determine whether precipitation fell as rain or snow. The datasets used in the precipitation-runoff modeling are available through a data release at https://doi. org/10.5066/P95NMIDF (Ostheimer and Huitger, 2019).

\section{Precipitation-Runoff Model Analyses}

The precipitation-runoff model was developed using precipitation data and calibrated to the streamflow data collected from May 2015 through February 2018. From the start of data collection, numerous runoff events have occurred within the basin. The 10 events (designated in the HEC-HMS as runs 1 through 10) with the highest peak streamflows (from May 2015 to February 2018 with stages above $5.5 \mathrm{ft}$ ) at the Bellville streamgage (station number 03131982) were used to calibrate and validate the HEC-HMS model. The model included 10 events but focused primarily on 6 peak streamflow events. Some of the events (runs 1 and 8) were not focused on because of high intensity summer storms that displayed highly variable rainfall distribution (observed in NWS produced hourly gridded rainfall files) throughout the basin. The other two events (runs 3 and 6) were not focused on because of the antecedent conditions for the model runs; the model needs time and precipitation amounts prior to the date of the peak to better match the observed results (further discussed in the appendix). The range of flows observed at the Bellville streamgage were from $1,610 \mathrm{ft}^{3} / \mathrm{s}$ (run 7) to $4,760 \mathrm{ft}^{3} / \mathrm{s}$ (run 10); listed in table 6 . Each model run (runs 1 through 10) listed in table 6 represent an event date. The range of flows are all less than the 10-percent annual exceedance-probability flood-peak streamflow of $5,400 \mathrm{ft}^{3} / \mathrm{s}$. The model was calibrated using one event on January 12, 2017 (run 5). The model was verified using five events - a mild-winter event on December 27, 2015 (run 2), a spring event on April 11, 2016 (run 4), a late spring event on May 5, 2017 (run 7), a late fall event on November 19, 2017 (run 9), and an early spring event on February 25, 2018 (run 10). These six model runs had satisfactory to good results. The Nash-Sutcliffe model efficiency coefficient is a goodness of fit statistic, where a value closer to one is a better match of simulated streamflow to observed (Nash and Sutcliffe, 1970). The model was considered "very good" with a value more than 0.75 , "good" with a value of 0.65 to 0.75 , "satisfactory" with a value of 0.5 to 0.65 , and "unsatisfactory" if values were less than 0.5 . The other four model runs had unsatisfactory results; the June and July events (runs 1 and 8) were high intensity summer storms that showed highly variable gridded rainfall distribution throughout the basin. The gridded daily precipitation totals indicate most rain fell in the Southwest to Southeast regions of the basin and the coefficients of variation of the gridded rainfall were 72,34 , and 25 percent for June 14, 15, and 16, 2015, respectively. Similar high percentages for the coefficients of variation were $19,37,65$, and 38 percent for July 10, 11, 12, and 13, 2017, respectively. The peak streamflow events are listed in table 6 . 
Table 6. Summary data from the U.S. Geological Survey streamgage Clear Fork Mohican River at Bellville, Ohio (station number 03131982), including the observed data from selected dates, estimates obtained using the HEC-HMS precipitation-runoff model, and the model performance statistics.

[All times are in Eastern Daylight Time; HEC-HMS, Hydrologic Engineering Center-Hydrologic Modeling System; \%, percent]

\begin{tabular}{|c|c|c|c|c|c|c|c|c|c|c|}
\hline $\begin{array}{l}\text { Location description Clear Fork } \\
\text { Mohican River and model output } \\
\text { statistic }\end{array}$ & $\begin{array}{c}\text { Run } 1 \\
6 / 16 / 2015\end{array}$ & $\begin{array}{c}\text { Run } 2 \\
12 / 27 / 2015\end{array}$ & $\begin{array}{c}\text { Run } 3 \\
2 / 24 / 2016\end{array}$ & $\begin{array}{c}\text { Run } 4 \\
\text { 4/11/2016 }\end{array}$ & $\begin{array}{c}\text { Run } 5 \\
1 / 12 / 2017\end{array}$ & $\begin{array}{c}\text { Run } 6 \\
2 / 7 / 2017\end{array}$ & $\begin{array}{c}\text { Run } 7 \\
5 / 5 / 2017\end{array}$ & $\begin{array}{c}\text { Run } 8 \\
\text { 7/13/2017 }\end{array}$ & $\begin{array}{c}\text { Run } 9 \\
11 / 19 / 2017\end{array}$ & $\begin{array}{c}\text { Run } 10 \\
2 / 25 / 2017\end{array}$ \\
\hline \multicolumn{11}{|c|}{ Peak streamflow for 10 events modeled and observed data (cubic foot per second) } \\
\hline $\begin{array}{l}\text { Observed data from } \\
\text { streamgage } 03131982\end{array}$ & $\begin{array}{c}2,350 \text { at } \\
07: 45 \text { a.m. }\end{array}$ & $\begin{array}{l}2,630 \text { at } \\
2: 15 \text { p.m. }\end{array}$ & $\begin{array}{l}1,770 \text { at } \\
5: 00 \text { p.m. }\end{array}$ & $\begin{array}{l}2,440 \text { at } \\
8: 45 \text { p.m. }\end{array}$ & $\begin{array}{l}3,050 \text { at } \\
7: 15 \text { p.m. }\end{array}$ & $\begin{array}{c}1,740 \text { at } \\
11: 00 \text { a.m. }\end{array}$ & $\begin{array}{l}1,610 \text { at } \\
3: 15 \text { p.m. }\end{array}$ & $\begin{array}{l}4,400 \text { at } \\
2: 15 \text { p.m. }\end{array}$ & $\begin{array}{c}\text { 4,310 at } \\
00: 30 \text { a.m. }\end{array}$ & $\begin{array}{l}4,760 \text { at } \\
07: 00 \text { a.m. }\end{array}$ \\
\hline $\begin{array}{l}\text { Simulated data from HEC-HMS } \\
\text { at the streamgage location, } \\
\text { hydrologic element "J480" }\end{array}$ & $\begin{array}{l}4,400 \text { at } \\
3: 45 \text { p.m. }\end{array}$ & $\begin{array}{l}2,650 \text { at } \\
2: 45 \text { p.m. }\end{array}$ & $\begin{array}{c}440 \text { at } \\
\text { 8:00 p.m. }\end{array}$ & $\begin{array}{c}1,780 \text { at } \\
11: 20 \text { p.m. }\end{array}$ & $\begin{array}{l}3,470 \text { at } \\
6: 40 \text { p.m. }\end{array}$ & $\begin{array}{c}2,730 \text { at } \\
12: 20 \text { p.m. }\end{array}$ & $\begin{array}{l}1,930 \text { at } \\
\text { 5:35 p.m. }\end{array}$ & $\begin{array}{l}6,250 \text { at } \\
2: 30 \text { p.m. }\end{array}$ & $\begin{array}{c}3,830 \text { at } \\
01: 40 \text { a.m. }\end{array}$ & $\begin{array}{c}4,340 \text { at } \\
06: 30 \text { a.m. }\end{array}$ \\
\hline \multicolumn{11}{|c|}{ Precipitation runoff models computed results and output statistics at the streamgage location } \\
\hline $\begin{array}{l}\text { Percentage error of the } \\
\text { simulated data relative to } \\
\text { the observed data }\end{array}$ & $87 \%$ & $1 \%$ & $-75 \%$ & $-27 \%$ & $14 \%$ & $57 \%$ & $20 \%$ & $42 \%$ & $-11 \%$ & $-9 \%$ \\
\hline $\begin{array}{l}\text { Nash-Sutcliffe model efficiency } \\
\text { coefficient }^{1}\end{array}$ & -8.99 & 0.459 & -0.993 & 0.611 & 0.851 & -0.310 & 0.633 & -5.07 & 0.715 & 0.729 \\
\hline Observed runoff volume (inches) & 1.27 & 1.61 & 1.80 & 2.61 & 1.67 & 3.11 & 1.90 & 2.62 & 2.48 & 4.47 \\
\hline Simulated runoff volume (inches) & 2.9 & 1.83 & 0.48 & 1.35 & 1.52 & 1.96 & 1.36 & 7.24 & 3.50 & 3.09 \\
\hline Residual runoff volume (inches) & -1.63 & -0.22 & 1.32 & 1.26 & 0.15 & 1.15 & 0.54 & -4.62 & -1.02 & 1.38 \\
\hline
\end{tabular}

${ }^{1}$ A goodness of fit statistic that is used to assess the predictive power of models, closer to one is a better match of simulated discharge to observed (Nash and Sutcliffe, 1970). 
The information described in the following sections summarizes the precipitation-runoff model analyses. Details about the development of the model and event model runs are in appendix 1 .

The initial estimates of loss and the transform parameters in the model runs were adjusted to better reproduce the observed peak streamflows. Compared to initial estimates, CNs were lowered and lag times were increased to improve the fit of the model results with the observed data.

\section{Precipitation-Runoff Model Limitations}

The lack of precipitation data throughout the Clear Fork Mohican River Basin resulted in added uncertainty for the events. For all the events except two, the only precipitation gage within the $153-\mathrm{mi}^{2}$ basin was the USGS precipitation gage at Clear Fork Reservoir near Lexington, Ohio (station number 03131898). The use of that point measurement to determine the duration and intensity of precipitation throughout the basin was less than ideal — especially during spring and summer convective storms when rainfall characteristics are typically more spatially variable. The NWS recommended minimum density of precipitation gages is one gage per $30 \mathrm{mi}^{2}$ for a flood warning network (USACE, 2000). For the 153-mi study area basin, five or more gages would have been required to meet the NWS recommended density of precipitation gages. After discussions with the cooperator, another precipitation gage, USGS Rain Gage at Cedar Fork above Bellville, Ohio, (station number 403704082352300), was added to the basin on July 20,2017. The precipitation gage was colocated with the USGS streamgage Cedar Fork above Bellville, Ohio (station number 03131965). However, the data from the additional precipitation gage were not used in the modeling of the last two runoff events (November 19, 2017, and February 25, 2018; table 6) to be consistent with the modeling of the eight previous runoff events that only used data for the precipitation gage at Clear Fork Reservoir near Lexington, Ohio (station number 03131898).

The data collection period for model development was 2.5 years and each of the 10 runoff events during this period were less than the 10-percent annual exceedance-probability flood peak streamflow. Calibrating and verifying the model with smaller runoff events leads to uncertainty in simulating the larger runoff events (events with peak flows greater than the 10-percent annual exceedance-probability flood); therefore, if the model is used to simulate larger events, the model will need to be calibrated to a similarly sized storm event (USACE, 2000).

\section{Precipitation-Runoff Model Results}

Observed and simulated peak flows and the error of the simulated peak flow as a percentage of the observed peak flows for the Bellville streamgage (station number 03131982) are listed in table 6. The Nash-Sutcliffe model efficiency coefficient is a unitless goodness of fit statistic that is used to assess the predictive power of hydrologic model runs (Nash and Sutcliffe, 1970); efficiencies can range from $-\infty$ to 1 , and the closer to 1 the better the match of the simulated streamflow to the observed streamflow. The event on January 12, 2017 (run 5) was used to calibrate the model, the Nash-Sutcliffe coefficient was 0.851 and had the lowest residual runoff volume 0.15 inches. Five other runoff events were used to validate the model with streamflow peaks on December 27, 2015 (run 2), April 11, 2016 (run 4), May 5, 2017 (run 7), November 19, 2017 (run 9), and February 25, 2018 (run 10); the Nash-Sutcliffe coefficients ranged from 0.459 to 0.729 . The other four events had unsatisfactory results. All results are summarized in table 6 .

\section{Summary}

The U.S. Geological Survey (USGS), in cooperation with the Muskingum Watershed Conservancy District, (1) installed 2 streamgages, 1 lake-level gage, 2 precipitation gages, and 12 submersible pressure transducers; (2) developed a series of 9 digital flood-inundation maps (stages 9 to 17 feet [ft]) for the USGS streamgage Clear Fork Mohican River at Bellville, Ohio; and (3) developed a precipitation-runoff model for a portion of the Clear Fork Mohican River Basin. The hydraulic model used to develop the flood-inundation maps was part of a larger modeling effort to update the Flood Insurance Study for Richland County. The flood-inundation maps cover an approximate 2.5-mile reach of the Clear Fork Mohican River within and near the corporate limits of Bellville, Ohio. The precipitation-runoff model included a 153-square mile portion of the Clear Fork Mohican River Basin that extended from the headwaters near Mansfield, Ohio, downstream to Benedict Road, about 1 mile northeast of Butler, Ohio. The models produced by this study can be used to assess possible flood mitigation options and define flood hazard areas that could contribute to the protection of life and property.

The U.S. Army Corps of Engineers (USACE) Hydrologic Engineering Center's River Analysis System (HEC-RAS) and Hydrologic Engineering Center's GeoRiver Analysis System (HEC-GeoRAS) programs were used to compute water-surface profiles and to help delineate estimated flood-inundation areas and depths of flooding for selected stream stages. For 16 measured events, the HEC-RAS hydraulic model was calibrated to the stage-streamflow relation at the USGS streamgage Clear Fork Mohican River at Bellville, Ohio (station number 03131982), and to water levels recorded by a submersible pressure transducer at Clear Fork Mohican River below Bellville, Ohio (station number 403645082300300). The hydraulic model was used to compute nine water-surface profiles at 1-foot increments for flood stages ranging from $9.0 \mathrm{ft}$ (near bankfull) to $17.0 \mathrm{ft}$ (approximately equal to the July 1987 flood peak) in 1-ft intervals. The simulated water-surface profiles were then 
used in combination with a digital elevation model derived from lidar data to delineate estimated flood-inundation areas and depth grids. These flood-inundation areas were overlain on high-resolution, georeferenced aerial photographs of the study area. The flood maps are available through a mapping application that can be accessed on the USGS Flood Inundation Mapping Science website (https://water.usgs.gov/ osw/flood_inundation) and on the National Weather Service Advanced Hydrologic Prediction Service website (https://water. weather.gov/ahps $2 /$ hydrograph.php?wfo=cle\&gage=bleo1).

Interactive use of the maps can give users a general indication of depth of water at any point by using the cursor to click within the shaded areas. These maps, in conjunction with the real-time stage data from the USGS streamgage Clear Fork Mohican River at Bellville, Ohio (station number 03131982) and forecasted flood stage data from the National Weather Service Advanced Hydrologic Prediction Service can help emergency planners and the public make more informed decisions about flood risk.

A precipitation-runoff model was developed using the USACE Hydrologic Engineering Center's Hydrologic Modeling System (HEC-HMS) with calibration and validation mainly focused on six peak streamflow events. All six runoff events during the 2.5 years of data collection were less than the 10-percent annual-exceedance probability flood peak streamflow. The Nash-Sutcliffe model efficiency coefficients for six peak streamflow events ranged from 0.459 to 0.851 . The models produced by this study can be used to assess possible flood mitigation options and define flood hazard areas that could contribute to the protection of life and property.

\section{References Cited}

Cross, W.P., and Brooks, H.P., 1959, Floods of January-February 1959 in Ohio: U.S. Geological Survey Circular 418, $54 \mathrm{p}$.

Esri, 2015, ArcGIS: accessed January 5, 2015, at https://www. esri.com/software/arcgis/.

Federal Emergency Management Agency, 2011, Flood Insurance Study, Richland County, Ohio, and incorporated areas: Washington D.C., Flood Insurance Study Number 39139CV000A, 102 p., accessed September 20, 2018, at https://www.richlandcountyoh.us/images/ BuildingDepartment/Docs/Richland\%20County $\% 20$ FIS\%2004042011.pdf.

Homer, C.G., Dewitz, J.A., Yang, L., Jin, S., Danielson, P., Xian, G., Coulston, J., Herold, N.D., Wickham, J.D., and Megown, K., 2015, Completion of the 2011 National Land Cover Database for the conterminous United StatesRepresenting a decade of land cover change information: American Society for Photogrammetric Engineering and Remote Sensing, v. 81, no. 5, p. 345-354.
Mayo, R.I., and Mangus, J.P., 1989, Flood of July 1-2, 1987, in north-central Ohio: U.S. Geological Survey Open File Report 89-376, 16 p.

Nash, J.E., and Sutcliffe, J.V., 1970, River flow forecasting through conceptual models part I-A discussion of principles: Journal of Hydrology, v. 10, no. 3, p. 282-290.

National Oceanic and Atmospheric Administration, 2018, Interactive snow information, MFD-Lahm Municipal Airport: National Operational Hydrologic Remote Sensing Center web page, accessed September 20, 2018, at https:// www.nohrsc.noaa.gov/interactive $/ \mathrm{html} / \mathrm{graph} . \mathrm{html}$ ?station= MFD\& $=600 \& h=400 \& o=a \& u c=0 \& b y=2013 \& b m=1 \& b d=$ $3 \& b h=6 \&$ ey $=2013 \&$ em $=1 \&$ ed $=23 \&$ eh $=6 \&$ data $=0 \&$ units $=0$ \&region $=$ us.

National Weather Service, 2018a, Advanced Hydrologic Prediction Service, Clear Fork Mohican River at Bellville: accessed September 20, 2018, at https://water.weather.gov/ ahps $2 /$ hydrograph.php?wfo=cle\&gage $=$ bleo 1 .

National Weather Service, 2018b, National Weather Service glossary: accessed September 20, 2018, at https:// w1.weather.gov/glossary/index.php?word=action+stage.

National Weather Service, 2018c, National Weather Service glossary: accessed September 20, 2018, at https:// w1.weather.gov/glossary/index.php?word=flood+categories.

Ohio Geographically Referenced Information Program, 2007, Ohio Statewide Imagery Program: accessed March 2, 2015, at http://ogrip.oit.ohio.gov/ProjectsInitiatives/ OSIPDataDownloads.aspx.

Ohio Geographically Referenced Information Program, 2018, Ohio Statewide Imagery Program: accessed September 20, 2018, at https:/ogrip.oit.ohio.gov/ ProjectsInitiatives/OSIPDataDownloads.aspx.

Ostheimer, C.J., and Huitger, C.A., 2019, Geospatial data sets for flood-inundation maps in and near Bellville, Ohio: U.S. Geological Survey data release, https://doi.org/10.5066/ P95NMIDF.

Rantz, S.E., and others, 1982, Measurement and computation of streamflow-Volume 1, Measurement of stage and discharge-Volume 2, Computation of discharge: U.S. Geological Survey Water-Supply Paper 2175, 631 p.

Richland County Regional Planning Commission, 2018, Home page: accessed June 30, 2017, at https://www.rcrpc.org.

Soil Survey Staff, Natural Resources Conservation Service, U.S. Department of Agriculture, 2018, Web Soil Survey: accessed September 20, 2018, at https://websoilsurvey.nrcs. usda.gov/. 
U.S. Army Corps of Engineers (USACE), 2000, Hydrologic modeling system HEC-HMS, technical reference manual: Hydrologic Engineering Center Report CPD-74B, 149 p.

U.S. Army Corps of Engineers (USACE), 2009, HEC-GeoRas, GIS tools for support of HEC-RAS using ArcGISUser's manual, version 4.2: Hydrologic Engineering Center Report CPD-83, [variously paged].

U.S. Army Corps of Engineers (USACE), 2010a, HEC-RAS River Analysis System, user's manual, version 4.1: Hydrologic Engineering Center Report CPD-68, 351 p.

U.S. Army Corps of Engineers (USACE), 2010b, HEC-RAS River Analysis System, hydraulic reference manual, version 4.1: Hydrologic Engineering Center Report CPD-69, 417 p.

U.S. Army Corps of Engineers (USACE), 2010c, HEC-RAS River Analysis System, applications guide, version 4.1: Hydrologic Engineering Center Report CPD-70, 351 p.

U.S. Army Corps of Engineers (USACE), 2010d, Geospatial hydrologic modeling extension, HEC-GeoHMS, user's manual, version 10.0: Hydrologic Engineering Center Report CPD-77, 197 p.

U.S. Army Corps of Engineers (USACE), 2016, Hydrologic modeling system, HEC-HMS, user's manual, version 4.2: Hydrologic Engineering Center Report CPD-74A, 614 p.

U.S. Census Bureau, 2018, Annual estimates of the resident population-April 1, 2010, to July 1, 2017, population estimates for Bellville, Ohio: accessed September 20, 2018, at https://factfinder.census.gov/faces/nav/jsf/pages/community_facts.xhtml? src $=$ bkmk.

U.S. Department of Agriculture, 2004, Part 630 hydrology national engineering handbook, chapter 10-Estimation of direct runoff from storm rainfall: Natural Resources Conservation Service Report 210-VI-NEH, 79 p., accessed September 20, 2018, at https://www.wcc.nrcs.usda.gov/ ftpref/wntsc/H\&H/NEHhydrology/ch10.pdf.

U.S. Geological Survey, 2018a, USGS 03131965 Cedar Fork above Bellville, Ohio: U.S. Geological Survey National Water Information System, accessed September 20, 2018, at https://waterdata.usgs.gov/oh/nwis/inventory/?site no $=03131965$.

U.S. Geological Survey (USGS), 2018b, USGS 03131982 Clear Fork Mohican River at Bellville, Ohio: U.S. Geological Survey National Water Information System, accessed September 20, 2018, at https://waterdata. usgs.gov/oh/nwis/inventory/?site_no=03131982.

U.S. Geological Survey, 2018c, USGS 03131898 Clear Fork Reservoir near Lexington, Ohio: U.S. Geological Survey National Water Information System, accessed September 20, 2018, at https://waterdata.usgs.gov/oh/nwis/ inventory/?site_no $=03131898$.
U.S. Geological Survey, 2018d, USGS 403704082352300

Rain gage at Cedar Fork above Bellville, Ohio: U.S. Geological Survey National Water Information System, accessed September 20, 2018, at https://waterdata. usgs.gov/oh/nwis/inventory/?site_no $=403704082352300$.

U.S. Geological Survey, 2018e, USGS 404047082345000 Clear Fork Mohican River at Lexington, Ohio: U.S. Geological Survey National Water Information System, accessed September 20, 2018, at https://waterdata. usgs.gov/oh/nwis/inventory/?site_no=404047082345000.

U.S. Geological Survey, 2018f, USGS 403930082335600 Clear Fork Mohican River below Lexington, Ohio: U.S. Geological Survey National Water Information System, accessed September 20, 2018, at https://waterdata. usgs.gov/oh/nwis/inventory/?site_no=403930082335600.

U.S. Geological Survey, 2018g, USGS 03825082325900 Clear Fork Mohican River at Ritter Road above Bellville, Ohio: U.S. Geological Survey National Water Information System, accessed September 20, 2018, at https://waterdata. usgs.gov/oh/nwis/inventory/?site_no=403825082325900.

U.S. Geological Survey, 2018h, USGS 403729082320700 Clear Fork Mohican River above Bellville, Ohio: U.S. Geological Survey National Water Information System, accessed January 4, 2018, at https://waterdata.usgs. gov/oh/nwis/inventory/?site_no=403729082320700.

U.S. Geological Survey, 2018i, USGS 403645082300300 Clear Fork Mohican River below Bellville, Ohio: U.S. Geological Survey National Water Information System, accessed September 20, 2018, at https://waterdata. usgs.gov/oh/nwis/inventory/?site_no $=403645082300300$.

U.S. Geological Survey, 2018j, USGS 403606082282800 Clear Fork Mohican River above Butler, Ohio: U.S. Geological Survey National Water Information System, accessed September 20, 2018, at https://waterdata. usgs.gov/oh/nwis/inventory/?site_no $=403606082282800$.

U.S. Geological Survey, 2018k, USGS 03132000 Clear Fork at Butler, Ohio: U.S. Geological Survey National Water Information System, accessed September 20, 2018, at https://waterdata.usgs.gov/oh/nwis/inventory/?site_ no $=03132000$.

U.S. Geological Survey, 20181, USGS 03131975 Cedar Fork near Bellville, Ohio: U.S. Geological Survey National Water Information System, accessed September 20, 2018, at https://waterdata.usgs.gov/oh/nwis/inventory/?site no $=03131975$.

U.S. Geological Survey, 2018m, USGS 403557082285500 Honey Creek near Butler, Ohio: U.S. Geological Survey National Water Information System, accessed September 20, 2018, at https://waterdata.usgs.gov/oh/nwis/ inventory/?site_no $=403557082285500$. 
U.S. Geological Survey, 2018n, USGS 403531082252600 Smoky Run at Butler, Ohio: U.S. Geological Survey National Water Information System, accessed

September 20, 2018, at https:/waterdata.usgs.gov/oh/nwis/ inventory/?site_no $=403531082252600$.

U.S. Geological Survey, 2018o, USGS 403510082250800 Slater Run at Butler, Ohio: U.S. Geological Survey National Water Information System, accessed September 20, 2018, at https://waterdata.usgs.gov/oh/nwis/inventory/?site_ no $=403510082250800$.

U.S. Geological Survey, 2018p, USGS 403538082245500 Slater Run at Resort Drive at Butler, Ohio: U.S. Geological Survey National Water Information System, accessed September 20, 2018, at https://waterdata.usgs.gov/oh/nwis/ inventory/?site_no $=403538082245500$.
U.S. Geological Survey, 2018q, USGS surface-water data for the Nation: U.S. Geological Survey National Water Information System, accessed September 20, 2018, at https://waterdata.usgs.gov/nwis/sw.

U.S. Geological Survey, 2018r, USGS Flood Inundation Mapping Science: U.S. Geological Survey website, accessed September 20, 2018, at https://water.usgs.gov/osw/ flood inundation. 



\section{Appendix 1. Precipitation-Runoff Model Parameters, Event Data Collected, and Results for the Clear Fork Mohican River Basin}

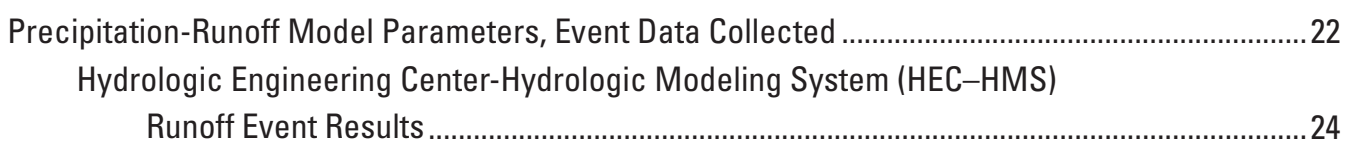

References Cited. 34

\section{Figures}

1.1. Screen shot from the U.S. Army Corps of Engineers Hydrologic Engineering Center's Hydrologic Modeling System (HEC-HMS) precipitation-runoff model showing the temperature index parameter values used for the December 2015 event (run 2)..

1.2. Plot from the U.S. Army Corps of Engineers Hydrologic Engineering Center's Hydrologic Modeling System (HEC-HMS) precipitation-runoff model, run 1, showing simulated and observed streamflows at the U.S. Geological Survey streamgage Clear Fork Mohican River at Bellville, Ohio, streamgage (station number 03131982) and precipitation amounts observed at the USGS precipitation gage at Clear Fork Reservoir near Lexington, Ohio (station number 03131898) during May 27, 2015, through June 19, 2015

1.3. Plot from the U.S. Army Corps of Engineers Hydrologic Engineering Center's Hydrologic Modeling System (HEC-HMS) precipitation-runoff model, run 2, showing simulated and observed streamflows at the U.S. Geological Survey streamgage Clear Fork Mohican River at Bellville, Ohio (station number 03131982); precipitation amounts observed at the USGS precipitation gage at Clear Fork Reservoir near Lexington, Ohio (station number 03131898); and air temperature data observed at the Mansfield Lahm Municipal Airport (NWS station 14891/MFD) during December 24-31, 2015.

1.4. Plot from the U.S. Army Corps of Engineers Hydrologic Engineering Center's Hydrologic Modeling System (HEC-HMS) precipitation-runoff model, run 3, showing simulated and observed streamflows at the U.S. Geological Survey streamgage Clear Fork Mohican River at Bellville, Ohio (station number 03131982); precipitation amounts observed at the USGS precipitation gage at Clear Fork Reservoir near Lexington, Ohio (station number 03131898); and air temperature data observed at the Mansfield Lahm Municipal Airport (NWS station 14891/MFD) during February 5, 2016, through March 4, 2016

1.5. Plot from the U.S. Army Corps of Engineers Hydrologic Engineering Center's Hydrologic Modeling System (HEC-HMS) precipitation-runoff model, run 4, showing simulated and observed streamflows at the U.S. Geological Survey streamgage Clear Fork Mohican River at Bellville, Ohio (station number 03131982); precipitation amounts observed at the USGS precipitation gage at Clear Fork Reservoir near Lexington, Ohio (station number 03131898); and air temperature data observed at the Mansfield Lahm Municipal Airport (NWS station 14891/MFD) during April 6-15, 2016. 


\section{Figures-Continued}

1.6. Plot from the U.S. Army Corps of Engineers Hydrologic Engineering Center's Hydrologic Modeling System (HEC-HMS) precipitation-runoff model, run 5, showing simulated and observed streamflows at the U.S. Geological Survey streamgage Clear Fork Mohican River at Bellville, Ohio (station number 03131982); precipitation amounts observed at the USGS precipitation gage at Clear Fork Reservoir near Lexington, Ohio (station number 03131898); and air temperature data observed at the Mansfield Lahm Municipal Airport (NWS station 14891/MFD) during December 26, 2016, through January 15, 2017

1.7. Plot from the U.S. Army Corps of Engineers Hydrologic Engineering Center's Hydrologic Modeling System (HEC-HMS) precipitation-runoff model, run 6, showing simulated and observed streamflows at the U.S. Geological Survey streamgage Clear Fork Mohican River at Bellville, Ohio (station number 03131982); precipitation amounts observed at the USGS precipitation gage at Clear Fork Reservoir near Lexington, Ohio (station number 03131898); and air temperature data observed at the Mansfield Lahm Municipal Airport (NWS station 14891/MFD) during January 12, 2017, through February 10, 2017

1.8. Plot from the U.S. Army Corps of Engineers Hydrologic Engineering Center's Hydrologic Modeling System (HEC-HMS) precipitation-runoff model, run 7, showing simulated and observed streamflows at the U.S. Geological Survey streamgage Clear Fork Mohican River at Bellville, Ohio (station number 03131982) and precipitation amounts observed at the USGS precipitation gage at Clear Fork Reservoir near Lexington, Ohio (station number 03131898) during April 27, 2017, through May 10, 2017. 30

1.9. Plot from the U.S. Army Corps of Engineers Hydrologic Engineering Center's Hydrologic Modeling System (HEC-HMS) precipitation-runoff model, run 8 , showing simulated and observed streamflows at the U.S. Geological Survey streamgage Clear Fork Mohican River at Bellville, Ohio (station number 03131982) and precipitation amounts observed at the USGS precipitation gage at Clear Fork Reservoir near Lexington, Ohio (station number 03131898) during June 20, 2017, through July 17, 2017

1.10. Plot from the U.S. Army Corps of Engineers Hydrologic Engineering Center's Hydrologic Modeling System (HEC-HMS) precipitation-runoff model, run 9 , showing simulated and observed streamflows at the U.S. Geological Survey streamgage Clear Fork Mohican River at Bellville, Ohio (station number 03131982); precipitation amounts observed at the USGS precipitation gage at Clear Fork Reservoir near Lexington, Ohio (station number 03131898); and air temperature data observed at the Mansfield Lahm Municipal Airport (NWS station 14891/MFD) during November 5-21, 2017

1.11. Plot from the U.S. Army Corps of Engineers Hydrologic Engineering Center's Hydrologic Modeling System (HEC-HMS) precipitation-runoff model, run 10, showing simulated and observed streamflows at the U.S. Geological Survey streamgage Clear Fork Mohican River at Bellville, Ohio (station number 03131982); precipitation amounts observed at the USGS precipitation gage at Clear Fork Reservoir near Lexington, Ohio (station number 03131898); and air temperature data observed at the Mansfield Lahm Municipal Airport (NWS station 14891/MFD) during February 19-26, 2018 


\section{Tables}

1.1. Values from the Hydrologic Engineering Center-Hydrologic Modeling System (HEC-HMS) precipitation-runoff model antecedent temperature index (ATI) melt-rate function used for the model during the seven cold-period events (December 2015, run 2).

1.2. Values from the Hydrologic Engineering Center-Hydrologic Modeling System (HEC-HMS) precipitation-runoff model antecedent temperature index (ATI) cold-rate function used for the model during the seven cold-period events

(December 2015, run 2). 


\section{Appendix 1. Precipitation-Runoff Model Parameters, Event Data Collected, and Results for the Clear Fork Mohican River Basin}

\section{Precipitation-Runoff Model Parameters and Event Data Collected}

The U.S. Army Corps of Engineers (USACE) Hydrologic Engineering Center's Hydrologic Modeling System (HEC-HMS) version 4.2 (USACE, 2016) was used to develop a precipitation-runoff model for the Clear Fork Mohican River Basin. Precipitation, streamflow, and stage data were collected by the U.S. Geological Survey (USGS) from May 2015 through February 2018 for model inputs, calibration, and validation of the model. The model was developed, calibrated, and verified using 10 high flow events (designated in HEC-HMS as run 1 through 10) from May 2015 through February 2018; gage stages above 5.5 feet (ft) were considered higher streamflows. The range of flows observed at the USGS streamgage Clear Fork Mohican River at Bellville, Ohio (station number 03131982; hereafter referred to as the "Bellville streamgage") were from 1,610 to 4,760 cubic feet per second $\left(\mathrm{ft}^{3} / \mathrm{s}\right.$ ) (runs 7 and 10, respectively; table 6). These flows are all less than the 10-percent annual exceedanceprobability peak streamflow of 5,400 $\mathrm{ft}^{3} / \mathrm{s}$. The model was calibrated using one event on January 12, 2017 (run 5). This event was in mild winter conditions with air temperatures ranging from 32 to 65 degrees Fahrenheit $\left({ }^{\circ} \mathrm{F}\right)$, and the precipitation fell as rain during this event; most of the rain fell when temperatures were between 40 and $65^{\circ} \mathrm{F}$. The model was verified using five events - a mild winter event on December 27, 2015 (run 2), a spring event on April 11, 2016 (run 4), a late spring event on May 5, 2017 (run 7), late fall event on November 19, 2017 (run 9), and an early spring event on February 25, 2018 (run 10). These events happened with mild temperatures above freezing and all precipitation falling as rain. These six events had satisfactory to good results; the other four events had unsatisfactory results. Three of the four events with unsatisfactory results, where the simulated model flows are overestimated, happened on June 16, 2015 (run 1), February 7, 2017 (run 6), and July 13, 2017 (run 8). These three events had multiple days prior to the event with 0.5 to 3.0 inches (in.) of rain in a 24-hour period. The day of each peak streamflow event had intense rainfall, June 16, 2015 (run 1) had 1.25 in. of rain, February 7, 2017 (run 6) had 0.9 in. of rain, and July 13, 2017 (run 8) had 1.14 in. of rain.
The combination of the wet antecedent conditions and intense peak rainfalls resulted in the model overestimating the flow resulting in an erroneous result; however, the result is conservative. In addition, high intensity storms in summer, the June and July events (runs 1 and 8) shows highly variable gridded rainfall distribution throughout the basin. The gridded daily precipitation totals indicate that most of the rain fell in the southwest to southeast parts of the basin and the coefficients of variation of the gridded rainfall were 72, 34, and 25 percent for June 14, 15, and 16, 2015, respectively. Similar high percentages for the coefficients of variation were 19,37, 65, and 38 percent for July 10, 11, 12, and 13, 2017, respectively.

Even though all the events happened during mild temperatures and the precipitation fell as rain, the models still used the temperature index method because temperatures were below freezing during a limited time for 7 of 10 events. The model was developed using the temperature index method to compute the amount of snowpack melt for each degree above freezing and the subbasin band approach (USACE, 2016). These events happened during the winter and had variable air temperatures with precipitation falling on potentially frozen ground. The results of these events were little to no snow melt or little to no rain falling on snow; these events were mild temperature winter events. Therefore, the same temperature index parameter values were used for these seven events, the wet melt rates were also the same. The wet melt rates represent the rate at which the snowpack melts when rain is falling on the snowpack, and the rates are used during time intervals when precipitation is falling as rain (USACE, 2016). The wet melt rates used for the events were 0.15 in. per degrees Fahrenheit-day (table 1.1). The temperature index parameters used in HEC-HMS for the seven winter events are shown in figure 1.1.

The same antecedent temperature index melt-rate function values were used to calculate a melt rate from the current melt rate index; antecedent temperature index cold-rate function values were used to update the antecedent cold content index from one time interval to the next (USACE, 2016) for the cold temperature period events (tables 1.1 and 1.2).

The HEC-HMS model constructed for the Clear Fork Mohican River Basin contains 20 reaches and 42 subbasins ranging in area from 0.049 to 16.6 square miles. Each subbasin includes the parameter data to calculate the air temperatures at different elevation bands (USACE, 2016). All cold-period events modeled use the same lapse rate of $-3.5^{\circ} \mathrm{F}$ per 1,000 ft with only one subbasin elevation band (because of the flat terrain of all the subbasins modeled). An initial snow water equivalent in inches was assigned to each subbasin to simulate the starting conditions. In the seven events with temperatures below freezing, no snow was on the ground when the simulations began. 


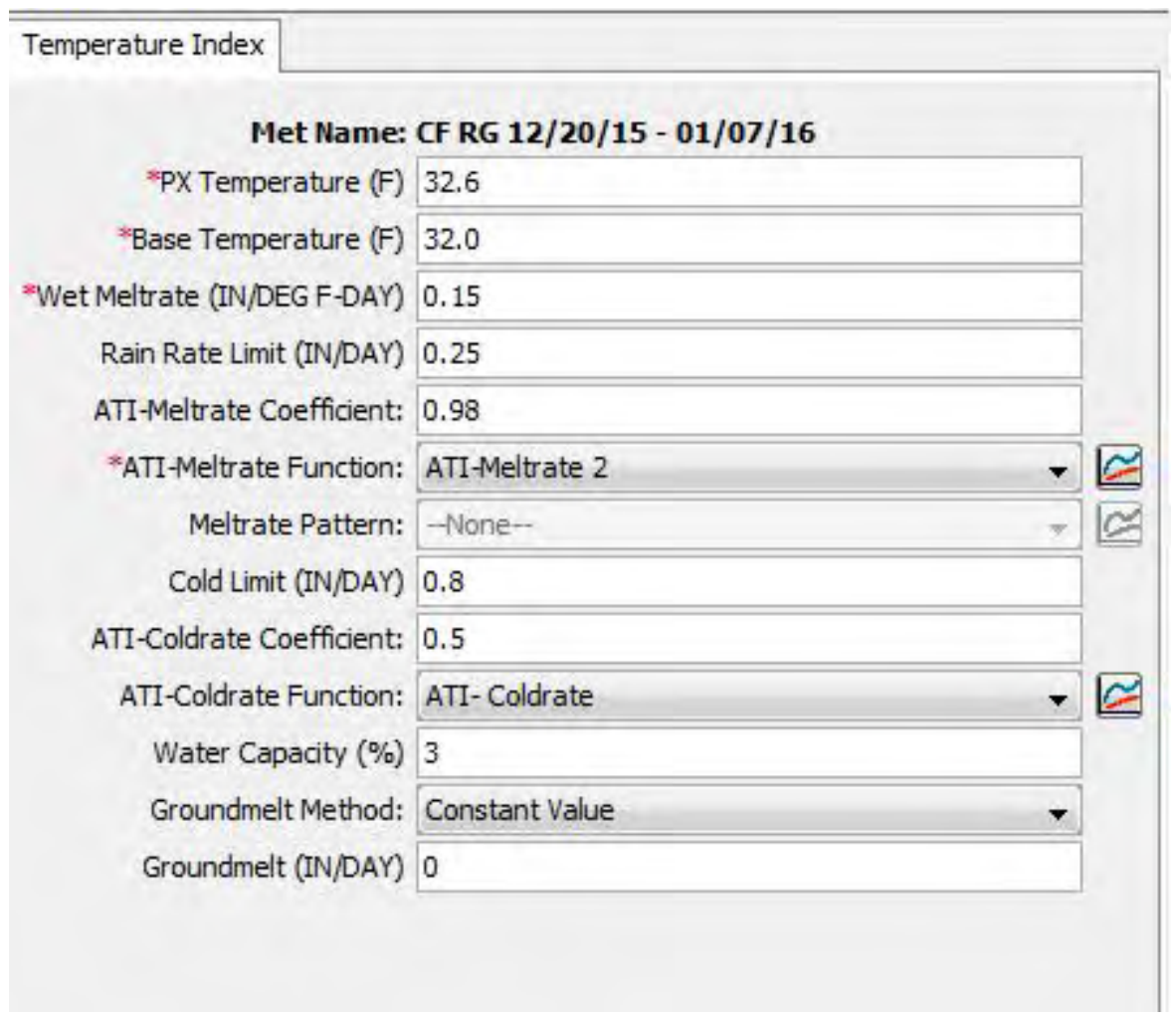

Figure 1.1. Screen shot from the U.S. Army Corps of Engineers Hydrologic Engineering Center's Hydrologic Modeling System (HEC-HMS) precipitation-runoff model showing the temperature index parameter values used for the December 2015 event (run 2).

Table 1.1. Values from the Hydrologic Engineering CenterHydrologic Modeling System (HEC-HMS) precipitation-runoff model antecedent temperature index (ATI) melt-rate function used for the model during the seven cold-period events (December 2015, run 2).

[F, Fahrenheit; inches/degree F-day, inches per degree Fahrenheit-day]

\begin{tabular}{cc}
\hline ATI (degree F-day) & Melt rate (inches/degree F-day) \\
\hline 0 & 0.15 \\
100 & 0.15 \\
200 & 0.15 \\
\hline
\end{tabular}

Table 1.2. Values from the Hydrologic Engineering CenterHydrologic Modeling System (HEC-HMS) precipitation-runoff model antecedent temperature index (ATI) cold-rate function used for the model during the seven cold-period events (December 2015, run 2).

[F, Fahrenheit; inches/degree F-day, inches per degree Fahrenheit-day]

\begin{tabular}{cc}
\hline ATI (degree F-day) & Cold rate (inches/degree F-day) \\
\hline 0 & 0.02 \\
100 & 0.02 \\
200 & 0.02 \\
\hline
\end{tabular}




\section{Hydrologic Engineering Center-Hydrologic Modeling System (HEC-HMS) Runoff Event Results}

A runoff event (hereafter referred to as an "event") can happen as a result of rainfall, snowmelt, or both. The event on June 16, 2015, resulted in an observed peak stage of $8.02 \mathrm{ft}(1,118.10 \mathrm{ft}$ North American Vertical Datum of 1988 [NAVD 88]) at 07:45 a.m. with an associated streamflow of $2,350 \mathrm{ft}^{3} / \mathrm{s}$ at the Bellville streamgage (U.S. Geological Survey [USGS], 2018b) (fig. 2, table 6). The HEC-HMS simulation for this event (run 1) commenced on May 27, 2015, and continued through June 20, 2015. The antecedent conditions were variable before the event based on data from the USGS precipitation gage at Clear Fork Reservoir near Lexington, Ohio (station number 03131898; hereafter referred to as the "precipitation gage"). Precipitation values were 0.5 in. on May 27; more than 1 in. on May 30-31; no rainfall during June 1-11; and small amounts of rain on June 12-14 for a total of 0.33 in. during those three days. The precipitation gage data indicate that most of the rain that contributed to the peak flows fell between June 14 at 11:15 p.m. and June 16 at 08:30 a.m., totaling 2.3 in. of rain in 39 hours. Figure 1.2 shows the observed (red line) and simulated (blue line) streamflows at the Bellville streamgage (J480, in HEC-HMS) for May 27, 2015, through June 19, 2015, and the cumulative precipitation in inches (green line) measured at the precipitation gage. Overall, the model overestimated the simulated volume and peak flows and the simulated timing was delayed by 8 hours at the peak compared to the observed. The overestimated volume and peaks could be attributed to crop cover within the basin absorbing more of the observed flow than what is simulated in the model. In addition, the gridded rainfall data throughout the basin was highly variable with the coefficient of variation of 72,34 , and 25 percent on June 14 , 15 , and 16, 2015, respectively. The antecedent conditions were saturated on May 27-31, with approximately 2.0 in. of rain within the first 5 days of the model simulation.

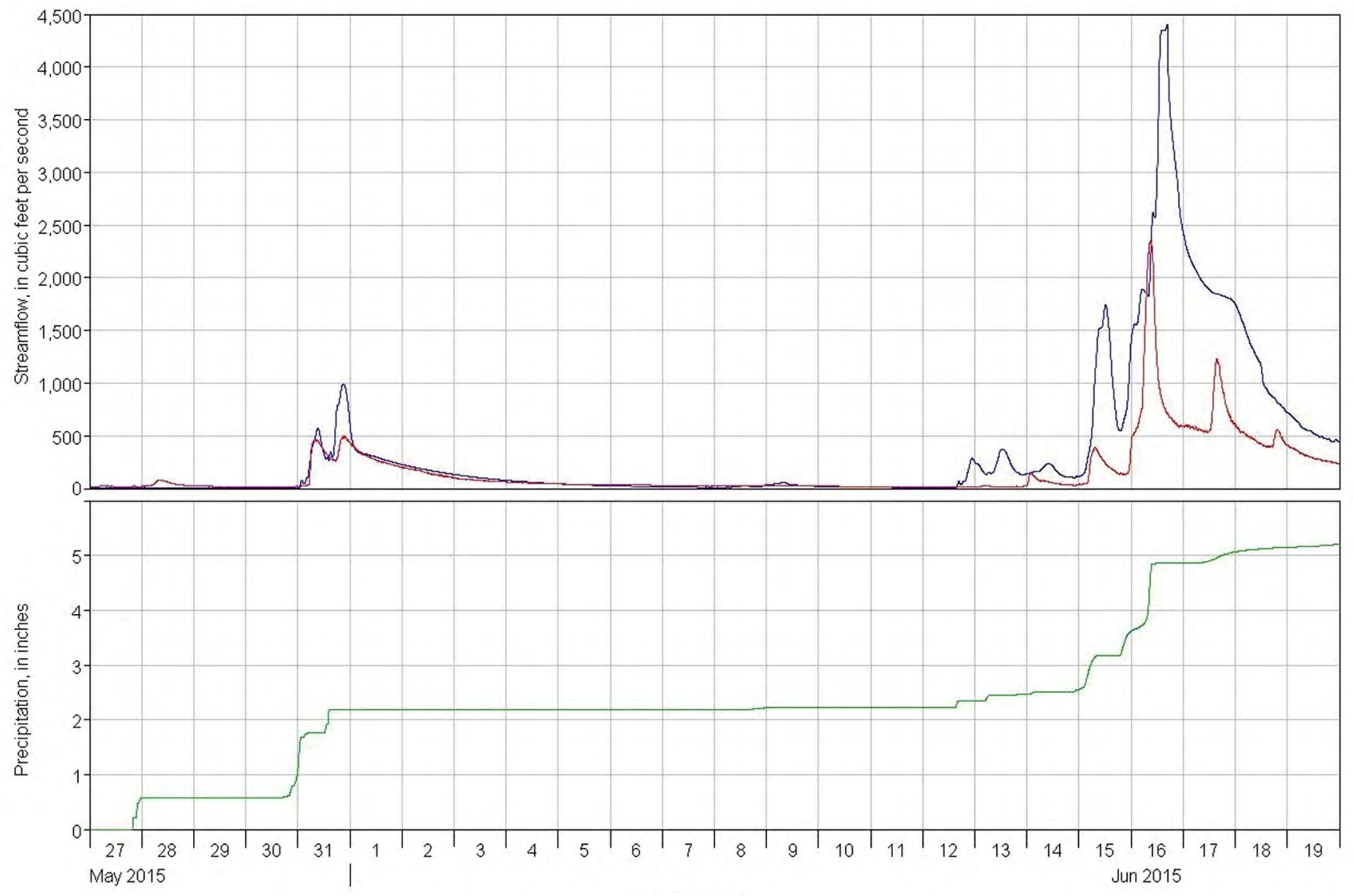

EXPLANATION

— Simulated streamflow from Hydrologic Engineering Center-Hydrologic Modeling System (HEC-HMS) at streamgage location, hydrologic element "J480"

- Observed streamflow at the U.S. Geological Survey streamgage Clear Fork Mohican River at Bellville, Ohio (station number 03131982)

— Precipitation (cumulative inches) observed at the Clear Fork Reservoir near Lexington, Ohio, precipitation gage (U.S. Geological Survey station number 03131898)

Figure 1.2. Plot from the U.S. Army Corps of Engineers Hydrologic Engineering Center's Hydrologic Modeling System (HEC-HMS) precipitation-runoff model, run 1, showing simulated and observed streamflows at the U.S. Geological Survey streamgage Clear Fork Mohican River at Bellville, Ohio, streamgage (station number 03131982) and precipitation amounts observed at the USGS precipitation gage at Clear Fork Reservoir near Lexington, Ohio (station number 03131898) during May 27, 2015, through June 19, 2015. 
The December 27, 2015, event resulted in an observed peak stage of $8.43 \mathrm{ft}(1118.51 \mathrm{ft}$ NAVD 88$)$ at 2:15 p.m. with an associated streamflow of 2,630 $\mathrm{ft}^{3} / \mathrm{s}$ at the Bellville streamgage (USGS, 2018b) (fig. 2, table 6). The HEC-HMS simulation for this event (run 2) commenced on December 20, 2015, and continued through January 6,2016. The precipitation gage registered $2.01 \mathrm{in}$. of rain between December 26 at 3:45 p.m. and December 27 at 2:00 p.m. Figure 1.3 shows the observed (red line) and simulated (blue line) streamflows at the Bellville streamgage (J480, in HEC-HMS) for December 24-31, 2015, and the cumulative precipitation in inches (green line) measured at the precipitation gage. This event happened during winter; however, all precipitation fell as rain through December 27, the event peak, because of the mild winter conditions with temperatures ranging from $40^{\circ} \mathrm{F}$ to more than $60^{\circ} \mathrm{F}$ during the event. Air temperature data were observed at the NWS station Mansfield Lahm Municipal Airport (station number 14891/MFD; National Oceanic and Atmospheric Administration, 2018). Hereafter, the NWS station at Mansfield Lahm
Municipal Airport will be referred to as the "NWS station". The NWS station at the airport is approximately 14 miles north of Bellville in the adjacent basin (fig. 1). The precipitation data from the NWS station were used only to determine whether there was snow on the ground prior to a runoff event (the coldweather initial surface conditions); however, the temperature data were used in the precipitation-runoff model. No snow accumulation was on the ground at the start of the modeled coldweather events. The air temperature data were used throughout the event, to determine if the precipitation was falling as rain or snow. The timing of the simulated peak, 2:45 p.m., matched well with the observed peak 2:15 p.m. -the simulated peak time was only 30 minutes after the observed peak time. The residual runoff volume was -0.22 in., one of the lowest residual runoff volumes. The simulated peak flow was $2,650 \mathrm{ft}^{3} / \mathrm{s}$, 1 percent higher than the observed peak flow of $2,630 \mathrm{ft}^{3} / \mathrm{s}$. The Nash-Sutcliffe model efficiency coefficient was 0.459 , at the satisfactory range ( 0.5 to 0.65 is the satisfactory range).
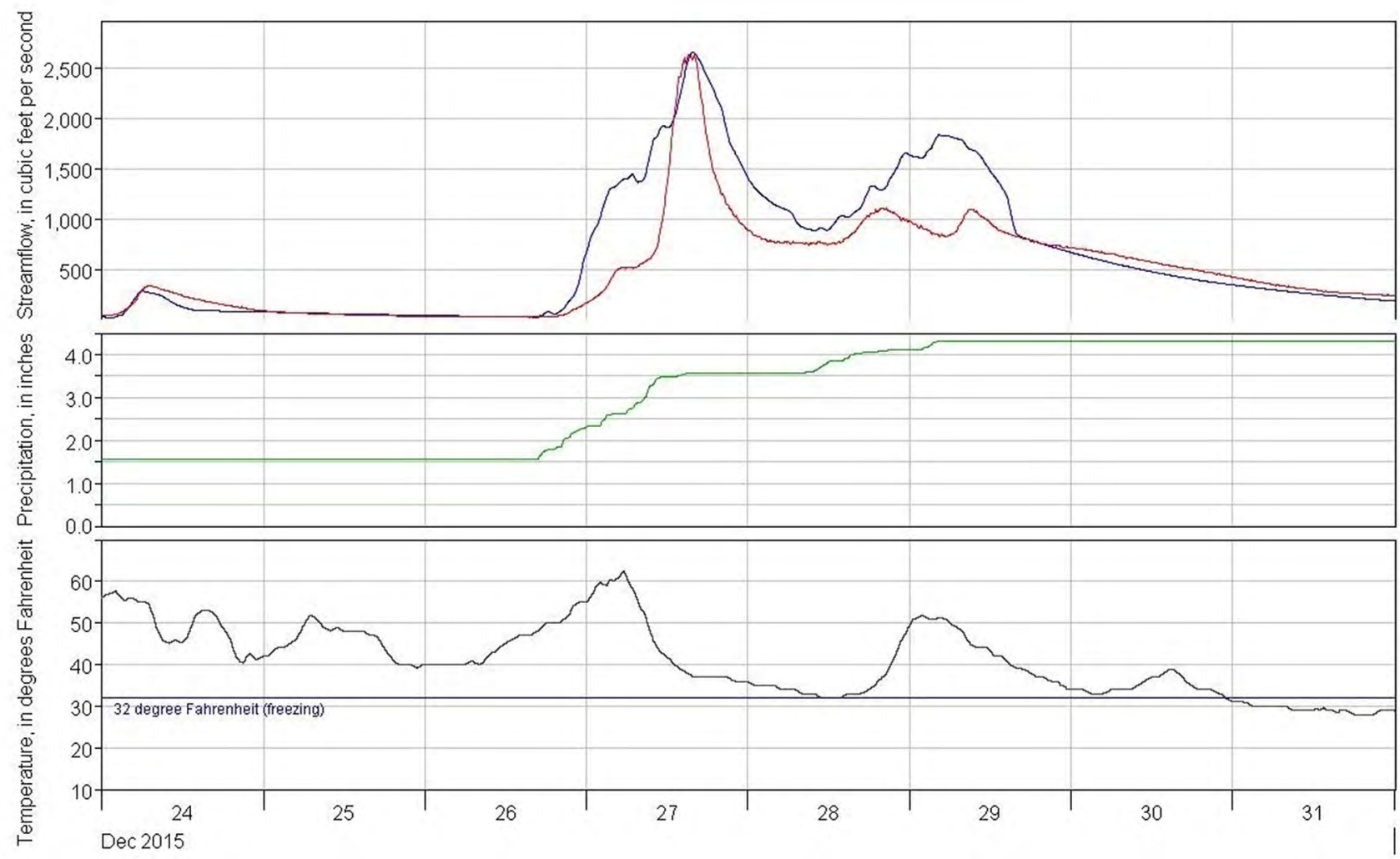

EXPLANATION

— Simulated streamflow from Hydrologic Engineering Center-Hydrologic Modeling System (HEC-HMS) at streamgage location, hydrologic element "J480"

_ Observed streamflow at the U.S. Geological Survey streamgage Clear Fork Mohican River at Bellville, Ohio (station number 03131982)

- Precipitation (cumulative inches) observed at the Clear Fork Reservoir near Lexington, Ohio, precipitation gage (U.S. Geological Survey station number 03131898)

— Air temperature (hourly) in degrees Fahrenheit, at the Municipal Mansfield Airport, Ohio (station number 14891/MFD)

Figure 1.3. Plot from the U.S. Army Corps of Engineers Hydrologic Engineering Center's Hydrologic Modeling System (HEC-HMS) precipitation-runoff model, run 2, showing simulated and observed streamflows at the U.S. Geological Survey streamgage Clear Fork Mohican River at Bellville, Ohio (station number 03131982); precipitation amounts observed at the USGS precipitation gage at Clear Fork Reservoir near Lexington, Ohio (station number 03131898); and air temperature data observed at the Mansfield Lahm Municipal Airport (NWS station 14891/MFD) during December 24-31, 2015. 
The event on February 24, 2016, resulted in an observed peak gage stage of $7.11 \mathrm{ft}(1,117.19 \mathrm{ft}$ NAVD 88) at 5:00 p.m. with an associated streamflow of $1,770 \mathrm{ft}^{3} / \mathrm{s}$ at the Bellville streamgage (USGS, 2018b) (fig. 2, table 6). The HEC-HMS simulation for this event (run 3) commenced on February 5, 2016, and continued through March 4, 2016. The antecedent conditions were dry before the event (less than 0.3 in. from February 5-23), and all precipitation fell the day of the event, on February 24, with 1.58 in. rain measured at the precipitation gage. Therefore, the simulation peak was extremely underestimated by 75 percent, but the timing of the simulation peak was close (approximately 3 hours later than the observed peak). Figure 1.4 shows the observed (red line) and simulated (blue line) streamflows at the Bellville streamgage (J480, in HEC-HMS) for February 5, 2016, through March 4, 2016, and the cumulative precipitation in inches (green line) measured at the precipitation gage.
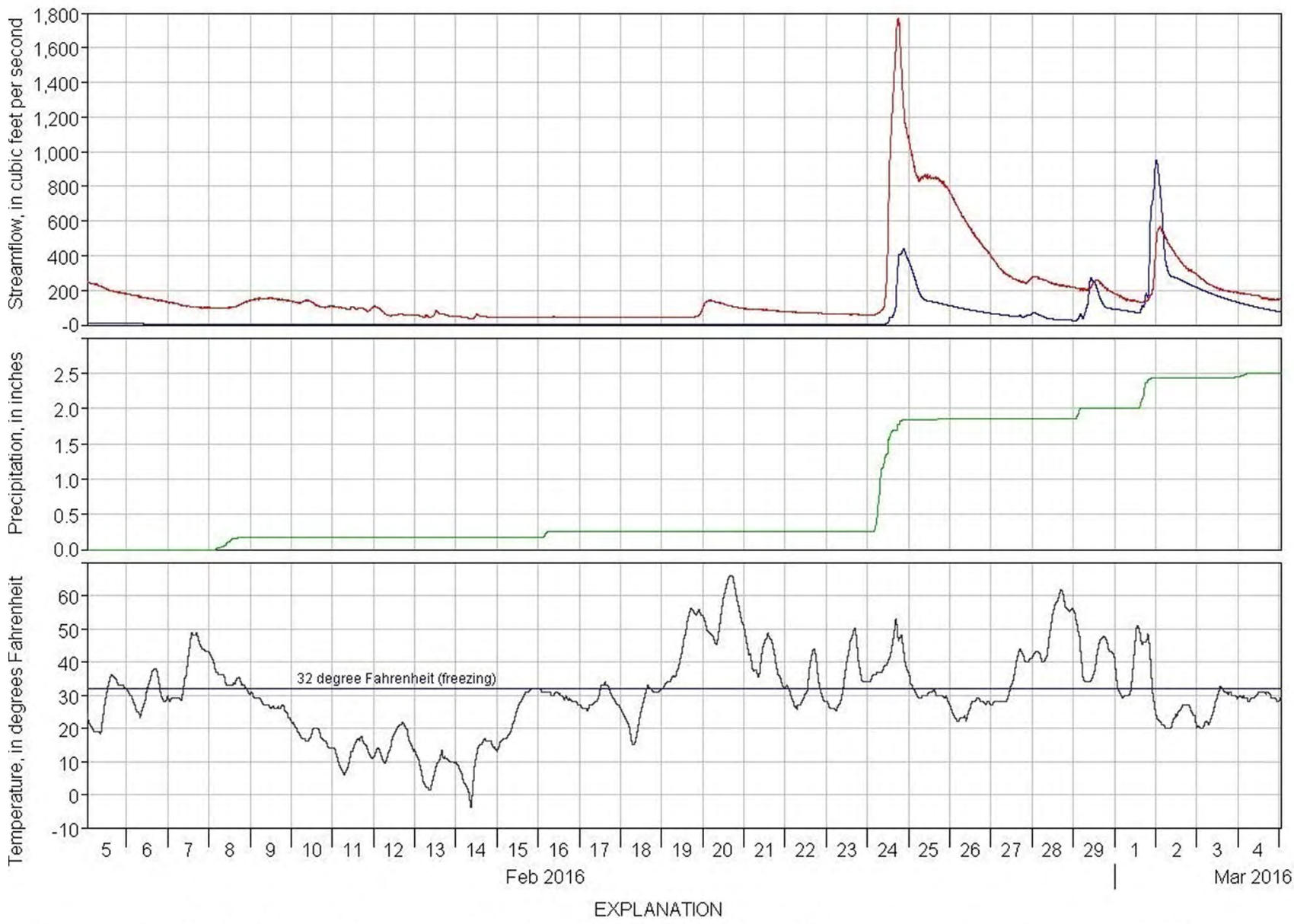

— Simulated streamflow from Hydrologic Engineering Center-Hydrologic Modeling System (HEC-HMS) at streamgage location, hydrologic element "J480"

— Observed streamflow at the U.S. Geological Survey streamgage Clear Fork Mohican River at Bellville, Ohio (station number 03131982)

_ Precipitation (cumulative inches) observed at the Clear Fork Reservoir near Lexington, Ohio, precipitation gage (U.S. Geological Survey station number 03131898)

- Air temperature (hourly) in degrees Fahrenheit, at the Municipal Mansfield Airport, Ohio (station number 14891/MFD)

Figure 1.4. Plot from the U.S. Army Corps of Engineers Hydrologic Engineering Center's Hydrologic Modeling System (HEC-HMS) precipitation-runoff model, run 3, showing simulated and observed streamflows at the U.S. Geological Survey streamgage Clear Fork Mohican River at Bellville, Ohio (station number 03131982); precipitation amounts observed at the USGS precipitation gage at Clear Fork Reservoir near Lexington, Ohio (station number 03131898); and air temperature data observed at the Mansfield Lahm Municipal Airport (NWS station 14891/MFD) during February 5, 2016, through March 4, 2016. 
The event on April 11, 2016, resulted in an observed peak gage stage of $8.16 \mathrm{ft}(1,118.24 \mathrm{ft}$ NAVD 88$)$ at $8: 45 \mathrm{p} . \mathrm{m}$. with an associated streamflow of $2,440 \mathrm{ft}^{3} / \mathrm{s}$ at the Bellville streamgage (USGS, 2018b) (fig. 2, table 6). The HEC-HMS simulation for this event (run 4) commenced on March 19, 2016, and continued through April 19, 2016. The antecedent conditions were saturated, with multiple spring rain showers and generally warm temperatures prior to the event; temperatures ranged from $30^{\circ} \mathrm{F}$ to more than $70^{\circ} \mathrm{F}$ from March 22 through April 1. The temperatures then tend to drop below freezing on partial days just prior to the event, on April 2-5 and April 8-10, temperatures range from $32^{\circ} \mathrm{F}$ to below $20^{\circ} \mathrm{F}$. The simulated peak is close in timing to the observed, the simulated peak is approximately 3 hours later than observed peak (fig. 1.5), but simulated peak and runoff volume were underestimated for the peak and the recession. A large difference between observed and simulated streamflows was during the peak on April 11, 2016, when the simulated peak flow was 27 percent smaller than the observed peak. The total residual runoff volume is underestimated in the simulation by 1.26 in. and the Nash-Sutcliffe model efficiency coefficient was 0.611. This spring event on April 11, 2016 (run 4), was used in the model validation; air temperatures were lower than usual for early spring. During April 9-10, 2016 , air temperatures ranged from 15 to $30^{\circ} \mathrm{F}$, likely resulting in a thin frozen layer on the ground surface and, therefore, resulting in more runoff (as observed peak data indicate).
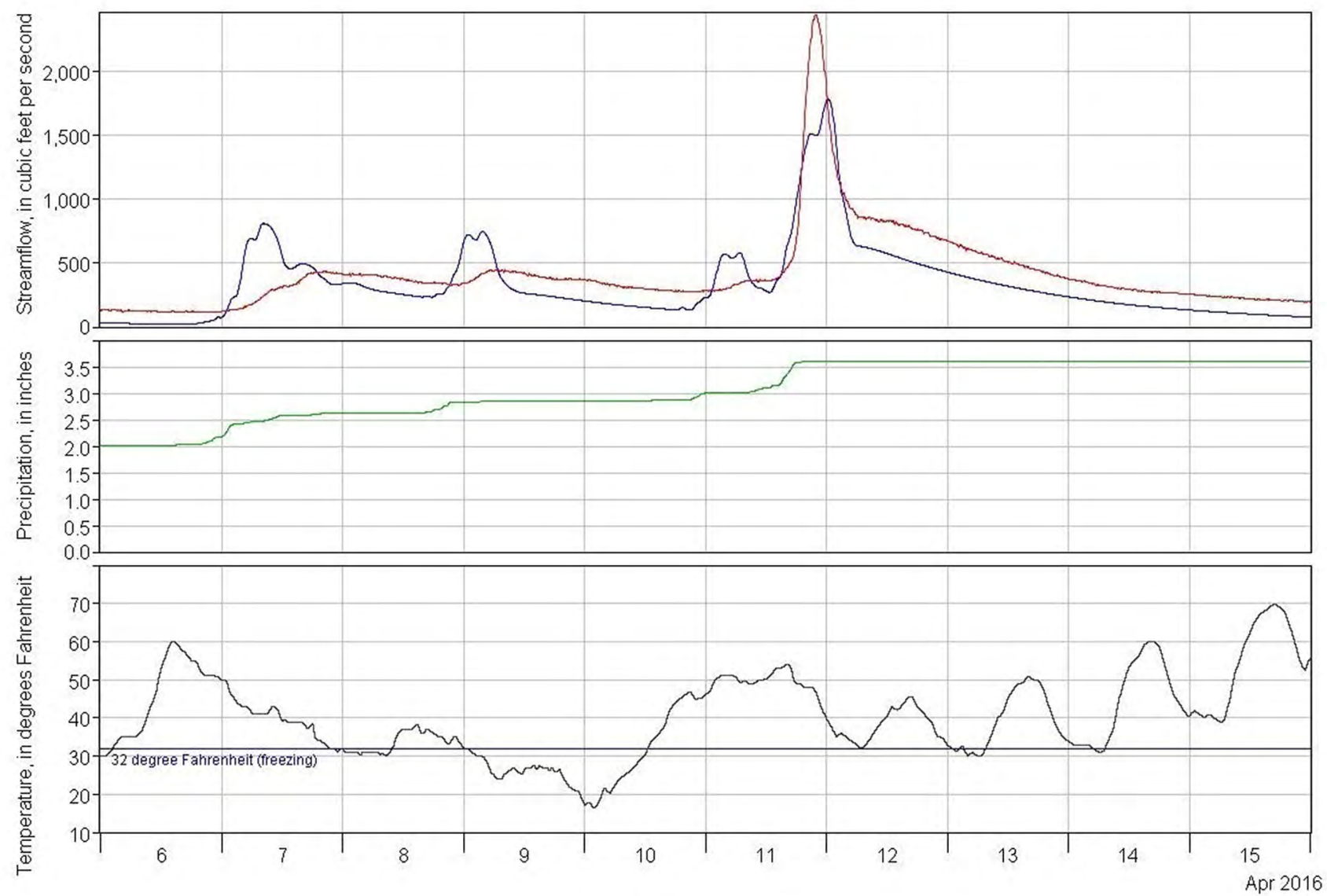

EXPLANATION

_ Simulated streamflow from Hydrologic Engineering Center-Hydrologic Modeling System (HEC-HMS) at streamgage location, hydrologic element "J480"

- Observed streamflow at the U.S. Geological Survey streamgage Clear Fork Mohican River at Bellville, Ohio (station number 03131982)

— Precipitation (cumulative inches) observed at the Clear Fork Reservoir near Lexington, Ohio, precipitation gage (U.S. Geological Survey station number 03131898)

_ Air temperature (hourly) in degrees Fahrenheit, at the Municipal Mansfield Airport, Ohio (station number 14891/MFD)

Figure 1.5. Plot from the U.S. Army Corps of Engineers Hydrologic Engineering Center's Hydrologic Modeling System (HEC-HMS) precipitation-runoff model, run 4, showing simulated and observed streamflows at the U.S. Geological Survey streamgage Clear Fork Mohican River at Bellville, Ohio (station number 03131982); precipitation amounts observed at the USGS precipitation gage at Clear Fork Reservoir near Lexington, Ohio (station number 03131898); and air temperature data observed at the Mansfield Lahm Municipal Airport (NWS station 14891/MFD) during April 6-15, 2016. 
The event on January 12, 2017, resulted in an observed peak gage stage of $8.98 \mathrm{ft}(1,119.06 \mathrm{ft}$ NAVD 88$)$ at 7:15 p.m. with an associated streamflow of $3,050 \mathrm{ft}^{3} / \mathrm{s}$ at the Bellville streamgage (USGS, 2018b) (fig. 2, table 6). The HEC-HMS simulation for this event (run 5) commenced on December 25, 2016, and continued through January 17, 2017. The antecedent conditions were well saturated, with approximately 0.7 in. of rain on December 26, 2016, and unusually warm temperatures above $60^{\circ} \mathrm{F}$. Another similar rainfall was on January 3, 2017, with warm temperatures above $50^{\circ} \mathrm{F}$. The following 6 days had below freezing temperatures that ranged from 25 to $0^{\circ} \mathrm{F}$. However, just prior to the event on January 10,2017 , temperatures rose to above $45^{\circ} \mathrm{F}$, with approximately $0.5 \mathrm{in}$. of rain and near freezing overnight temperatures. On January 11 and 12, temperatures ranged from 40 to $60^{\circ} \mathrm{F}$, with more than 1.6 in. of rain. Figure 1.6 shows the observed (red line) and simulated (blue line) streamflows at the Bellville streamgage (J480, in HECHMS) for December 26, 2016, through January 16, 2017; the cumulative precipitation in inches (green line) measured at the precipitation gage; and the air temperature data (black line) observed at the NWS station. This event was used to calibrate the model; overall, the simulated event matched up well to the observed data, and run 5 had the highest Nash-Sutcliffe model efficiency coefficient of 0.85 and the lowest residual runoff of $0.15 \mathrm{in}$. The timing of the simulated peak matched the observed peak with the simulated peak 35 minutes prior to the observed peak, and the simulated peak was 14 percent higher than the observed peak of $3,050 \mathrm{ft}^{3} / \mathrm{s}$.
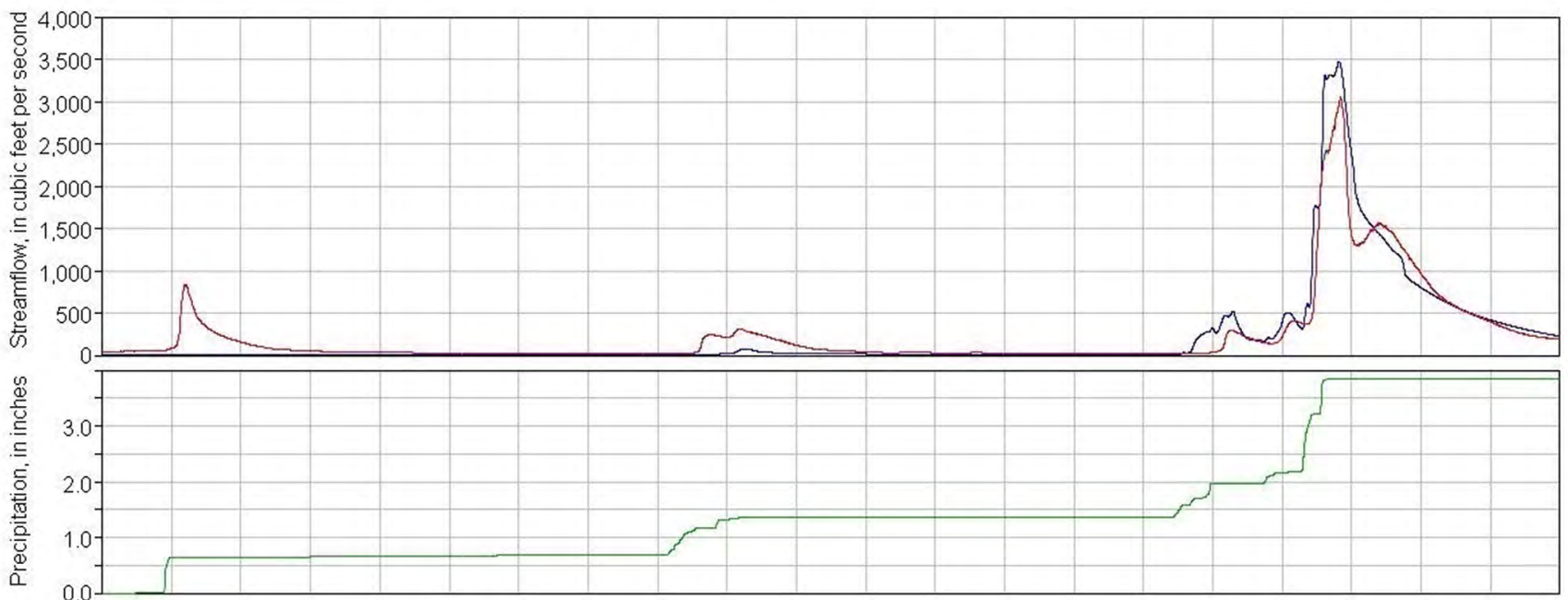

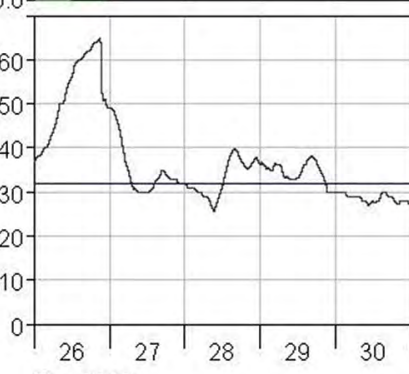

Dec 2016
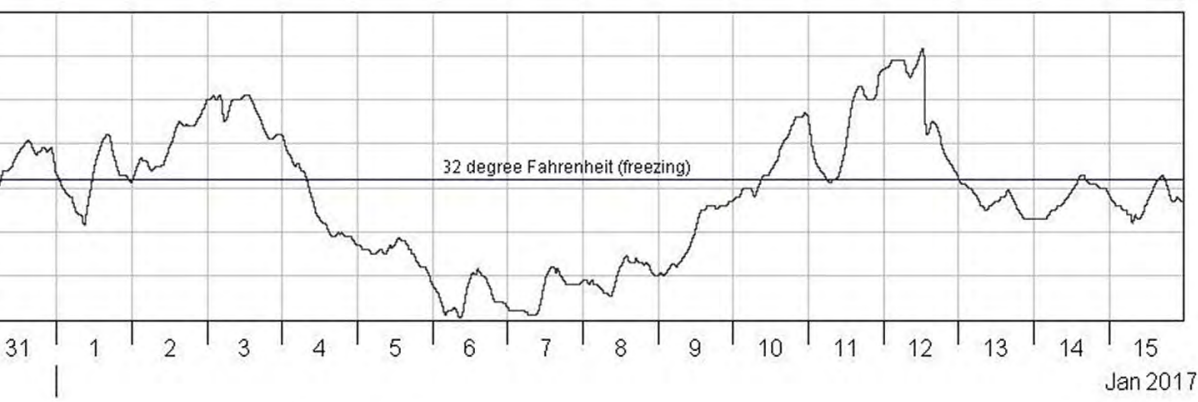

EXPLANATION

— Simulated streamflow from Hydrologic Engineering Center-Hydrologic Modeling System (HEC-HMS) at streamgage location, hydrologic element "J480"

_ Observed streamflow at the U.S. Geological Survey streamgage Clear Fork Mohican River at Bellville, Ohio (station number 03131982)

_ Precipitation (cumulative inches) observed at the Clear Fork Reservoir near Lexington, Ohio, precipitation gage (U.S. Geological Survey station number 03131898)

- Air temperature (hourly) in degrees Fahrenheit, at the Municipal Mansfield Airport, Ohio (station number 14891/MFD)

Figure 1.6. Plot from the U.S. Army Corps of Engineers Hydrologic Engineering Center's Hydrologic Modeling System (HEC-HMS) precipitation-runoff model, run 5, showing simulated and observed streamflows at the U.S. Geological Survey streamgage Clear Fork Mohican River at Bellville, Ohio (station number 03131982); precipitation amounts observed at the USGS precipitation gage at Clear Fork Reservoir near Lexington, Ohio (station number 03131898); and air temperature data observed at the Mansfield Lahm Municipal Airport (NWS station 14891/MFD) during December 26, 2016, through January 15, 2017. 
The event on February 7, 2017, resulted in an observed peak gage stage of $7.04 \mathrm{ft}(1,117.12 \mathrm{ft}$ NAVD 88$)$ at 11:00 a.m. with an associated streamflow of $1,740 \mathrm{ft}^{3} / \mathrm{s}$ at the Bellville streamgage (USGS, 2018b) (fig. 2, table 6). The HEC-HMS simulation for this event (run 6) commenced on January 12, 2017, and continued through February 10, 2017. The antecedent conditions were well saturated, with approximately 1.7 in. of rain on January 12 and multiple days with approximately $0.5 \mathrm{in}$. of rain per day; temperatures were unusually warm during these periods of rain. During January 27 through February 4, temperatures ranged from 15 to $35^{\circ} \mathrm{F}$. On February 5, temperatures rose to $45^{\circ} \mathrm{F}$ during the day and then dropped to below $25^{\circ} \mathrm{F}$ overnight. During February 6-7 temperatures ranged from $40-55^{\circ} \mathrm{F}$, with more than 1.0 in. of rain on February 7. Figure 1.7 shows the observed (red line) and simulated (blue line) streamflows at the Bellville streamgage (J480, in HEC-HMS) for January 12, 2017, through February 10, 2017; the cumulative precipitation in inches (green line) measured at the precipitation gage; and the air temperature data (black line) observed at the NWS station. Overall, this simulated event overestimated the peak by 57 percent, but the timing of the simulated model peak better matched the observed peak; the simulated peak was 80 minutes after the observed peak on February 7, 2017. Model run 6 for this event starts on January 12 , the same date of the peak event in the previous model, run 5. The results of run 5 indicate a good match between the simulated and observed, timing, peak, and overall volume. The same date of January 12 has the simulated flow underestimated at the start of run 6 . However, as the model run continues and more rain falls on January 17,20 , and 23 , the simulated flow overestimates but better matches the observed flow at these smaller peaks. On February 7 , an additional $1.0 \mathrm{in}$. of rain has the simulated flow overestimating the peak by 57 percent and the residual runoff volume by $1.15 \mathrm{in}$. These results indicate a common reaction to the initial start of the model; the model needs time and precipitation amounts prior to the date of the peak to better match the observed results.
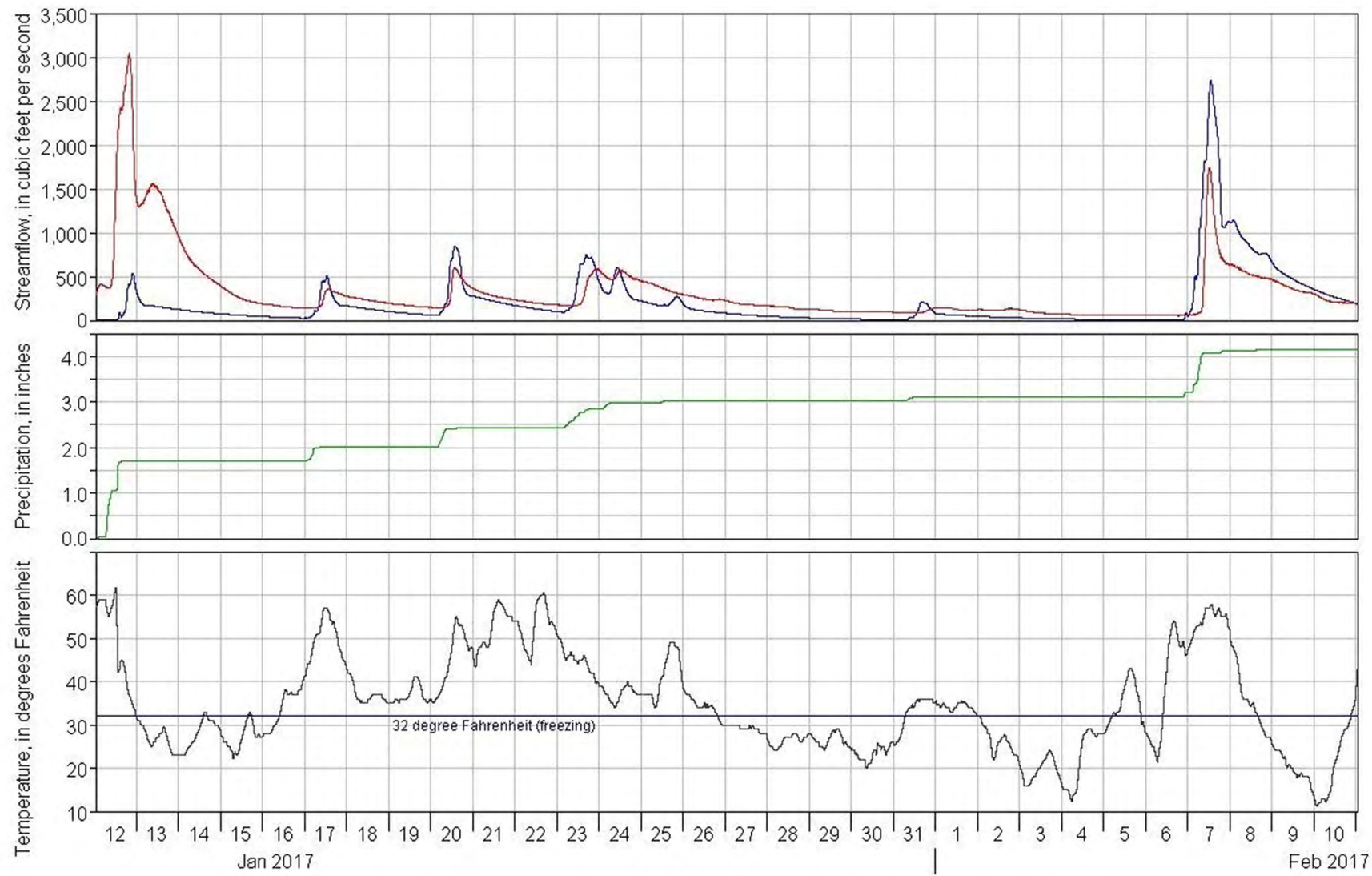

EXPLANATION

— Simulated streamflow from Hydrologic Engineering Center-Hydrologic Modeling System (HEC-HMS) at streamgage location, hydrologic element "J480"

— Observed streamflow at the U.S. Geological Survey streamgage Clear Fork Mohican River at Bellville, Ohio (station number 03131982)

_ Precipitation (cumulative inches) observed at the Clear Fork Reservoir near Lexington, Ohio, precipitation gage (U.S. Geological Survey station number 03131898)

— Air temperature (hourly) in degrees Fahrenheit, at the Municipal Mansfield Airport, Ohio (station number 14891/MFD)

Figure 1.7. Plot from the U.S. Army Corps of Engineers Hydrologic Engineering Center's Hydrologic Modeling System (HECHMS) precipitation-runoff model, run 6, showing simulated and observed streamflows at the U.S. Geological Survey streamgage Clear Fork Mohican River at Bellville, Ohio (station number 03131982); precipitation amounts observed at the USGS precipitation gage at Clear Fork Reservoir near Lexington, Ohio (station number 03131898); and air temperature data observed at the Mansfield Lahm Municipal Airport (NWS station 14891/MFD) during January 12, 2017, through February 10, 2017. 
The event on May 5, 2017, resulted in an observed peak gage stage of $6.79 \mathrm{ft}(1,116.87 \mathrm{ft}$ NAVD 88$)$ at 3:15 p.m. with an associated streamflow of $1,610 \mathrm{ft}^{3} / \mathrm{s}$ at the Bellville streamgage (USGS, 2018b) (fig. 2, table 6). The HECHMS simulation for this event (run 7) commenced on April 14, 2017, and continued through May 13, 2017. The antecedent conditions were well saturated, with multiple days of more than $0.5 \mathrm{in}$. of rain per day prior to the event. Figure 1.8 shows the observed (red line) and simulated (blue line) streamflows at the Bellville streamgage (J480, in HEC-HMS) for April 27, 2017, through May 10, 2017, and the cumulative precipitation in inches (green line) measured at the precipitation gage. Overall, the timing and magnitude of the simulated peak flow matched the observed well, with the simulated peak 2 hours and 20 minutes after the observed peak and the simulated peak flow 20 percent more than the observed peak of $1,610 \mathrm{ft}^{3} / \mathrm{s}$. For this validation model run, the residual runoff volume was $0.54 \mathrm{in}$. and the Nash-Sutcliffe model efficiency coefficient was 0.633 (table 6).
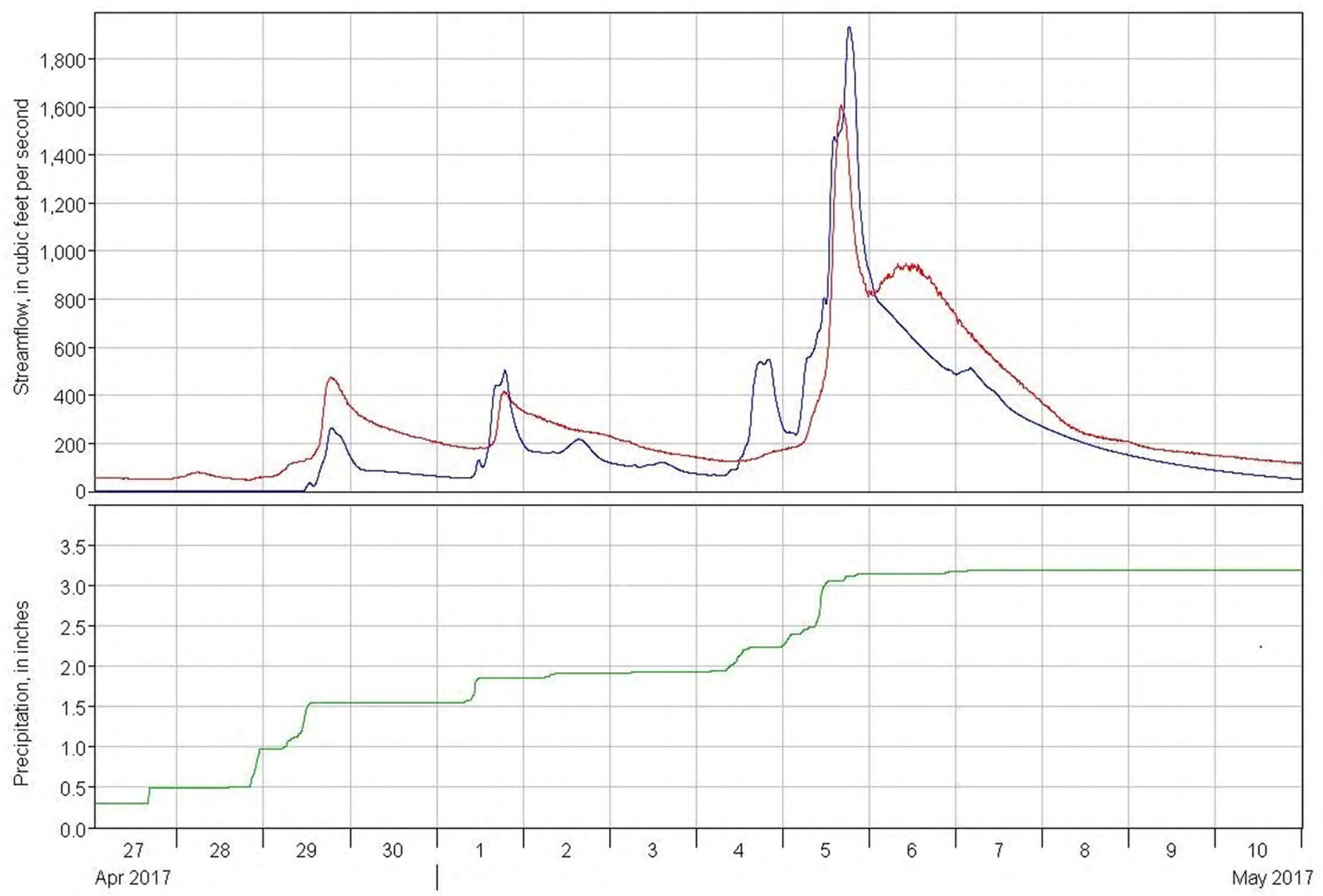

EXPLANATION

— Simulated streamflow from Hydrologic Engineering Center-Hydrologic Modeling System (HEC-HMS) at streamgage location, hydrologic element "J480"

- Observed streamflow at the U.S. Geological Survey streamgage Clear Fork Mohican River at Bellville, Ohio (station number 03131982)

_- Precipitation (cumulative inches) observed at the Clear Fork Reservoir near Lexington, Ohio, precipitation gage (U.S. Geological Survey station number 03131898)

Figure 1.8. Plot from the U.S. Army Corps of Engineers Hydrologic Engineering Center's Hydrologic Modeling System (HEC-HMS) precipitation-runoff model, run 7, showing simulated and observed streamflows at the U.S. Geological Survey streamgage Clear Fork Mohican River at Bellville, Ohio (station number 03131982) and precipitation amounts observed at the USGS precipitation gage at Clear Fork Reservoir near Lexington, Ohio (station number 03131898) during April 27, 2017, through May 10, 2017. 
The event on July 13,2017, resulted in an observed peak gage stage of $10.25 \mathrm{ft}(1,120.33 \mathrm{ft} \mathrm{NAVD} 88)$ at 2:15 p.m. with an associated streamflow of 4,400 $\mathrm{ft}^{3} / \mathrm{s}$ at the Bellville streamgage (USGS, 2018b) (fig. 2, table 6). The HEC-HMS simulation for this event (run 8) commenced on June 20, 2017 , and continued through July 18, 2017. The antecedent conditions were well saturated, with multiple days of more than 1.5 in. of rain per day prior to the event. During July 10-13, the observed rainfall was approximately 4 in., and the gridded rainfall was highly variable throughout the basin. The coefficients of variation were $19,37,65$, and 38 percent for July $10,11,12$, and 13, 2017, respectively. Figure 1.9 shows the observed (red line) and simulated (blue line) streamflows at the Bellville streamgage (J480, in HEC-HMS) for June 20, 2017, through July 17, 2017, and the cumulative precipitation in inches (green line) measured at the precipitation gage. Overall, the simulated event overestimated the observed peaks and total volume; however, the simulated timing for the peak on July 13 was similar to the observed timing, 15 minutes later than the observed peak time.

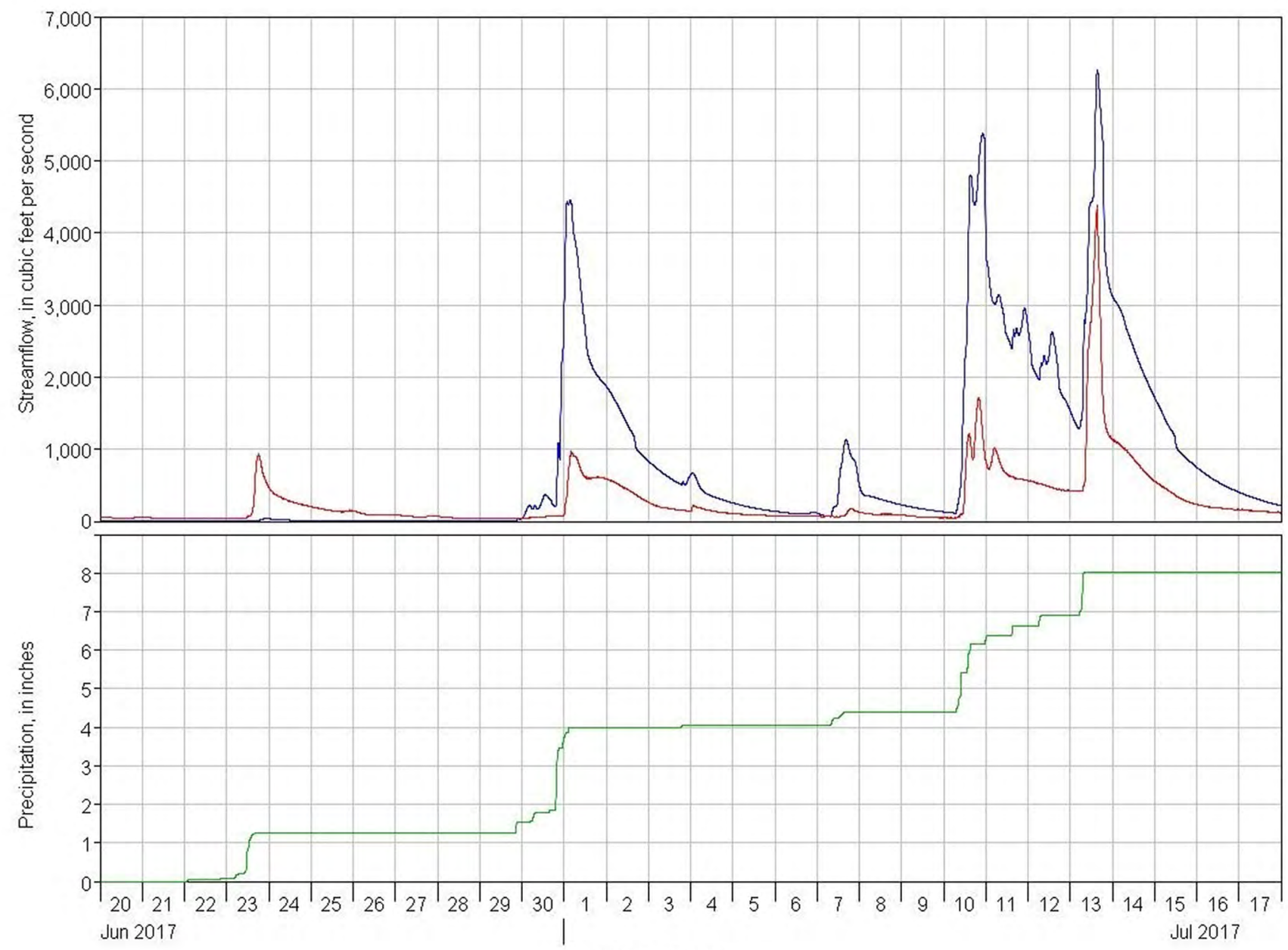

EXPLANATION

— Simulated streamflow from Hydrologic Engineering Center-Hydrologic Modeling System (HEC-HMS) at streamgage location, hydrologic element "J480"

- Observed streamflow at the U.S. Geological Survey streamgage Clear Fork Mohican River at Bellville, Ohio (station number 03131982)

_ Precipitation (cumulative inches) observed at the Clear Fork Reservoir near Lexington, Ohio, precipitation gage (U.S. Geological Survey station number 03131898)

Figure 1.9. Plot from the U.S. Army Corps of Engineers Hydrologic Engineering Center's Hydrologic Modeling System (HEC-HMS) precipitation-runoff model, run 8, showing simulated and observed streamflows at the U.S. Geological Survey streamgage Clear Fork Mohican River at Bellville, Ohio (station number 03131982) and precipitation amounts observed at the USGS precipitation gage at Clear Fork Reservoir near Lexington, Ohio (station number 03131898) during June 20, 2017, through July 17, 2017. 
The event on November 19, 2017, resulted in an observed peak gage stage of $10.36 \mathrm{ft}(1,120.44 \mathrm{ft}$ NAVD 88$)$ at 00:30 a.m. with an associated streamflow of $4,310 \mathrm{ft}^{3} / \mathrm{s}$ at the Bellville streamgage (USGS, 2018b) (fig. 2, table 6). The HEC-HMS simulation for this event (run 9) commenced on November 1, 2017, and continued through November 25, 2017. The antecedent conditions were saturated, with approximately 1.8 in. of rain on November 5 , warm temperatures ranging from $35^{\circ} \mathrm{F}$ to more than $60^{\circ} \mathrm{F}$ most of the days prior to the peak event, and a few days with temperatures below freezing on November 9-12 and late in the day on November 19,2017. Overall, the simulated results matched well with the observed results, timing and peaks matching well on November 6 and 19. The simulated peak on November 19 was 70 minutes later than the observed peak, and the simulated peak streamflow was 11 percent lower than the observed peak streamflow of $4,310 \mathrm{ft}^{3} / \mathrm{s}$. The Nash-Sutcliffe model efficiency coefficient was 0.715 , indicating a good validation run for the model. Figure 1.10 shows the observed (red line) and simulated (blue line) streamflows at the Bellville streamgage (J480, in HEC-HMS) for November 5-21, 2017; the cumulative precipitation in inches (green line) measured at the precipitation gage; and the air temperature data (black line) observed at the NWS station.
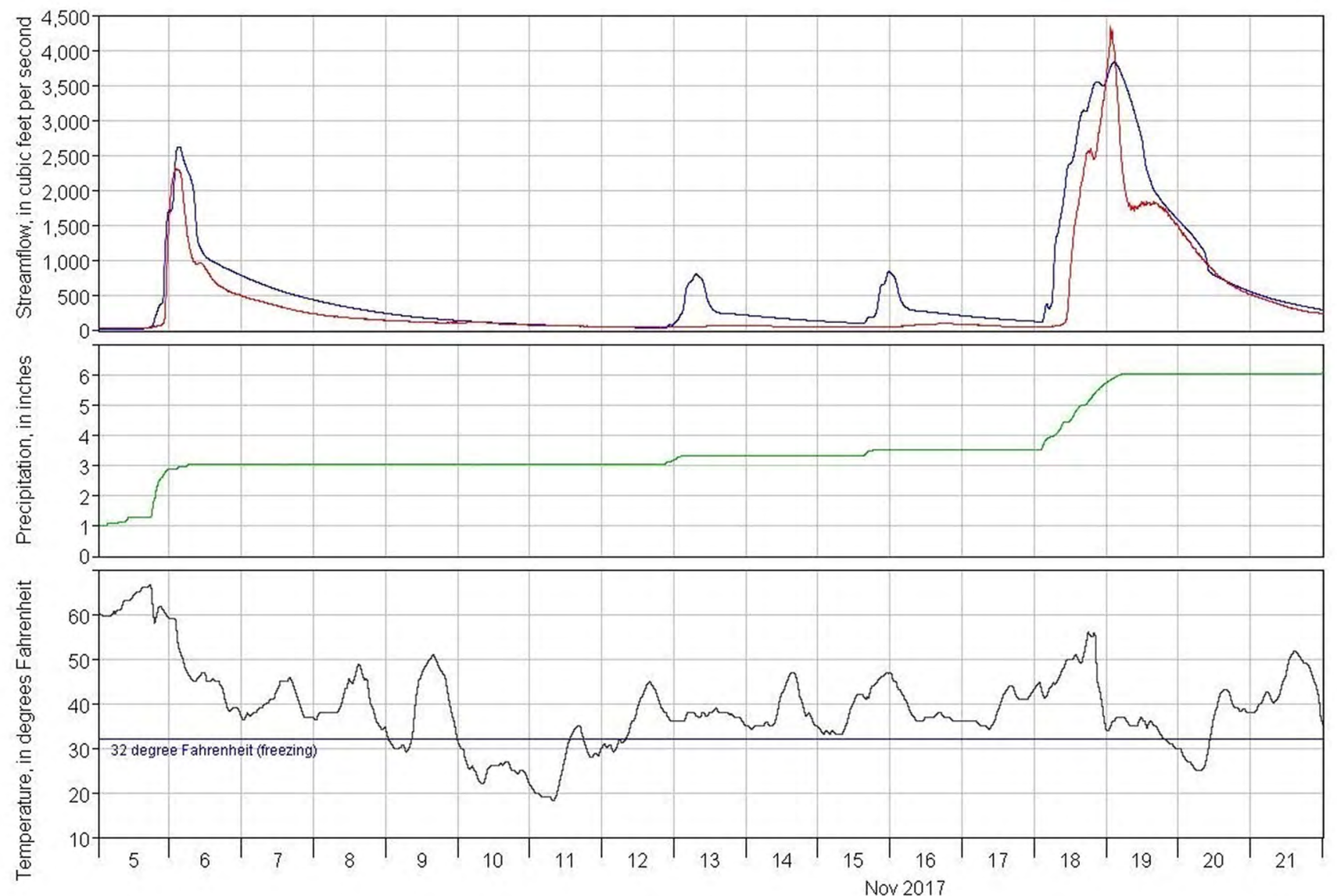

EXPLANATION

— Simulated streamflow from Hydrologic Engineering Center-Hydrologic Modeling System (HEC-HMS) at streamgage location, hydrologic element "J480"'

— Observed streamflow at the U.S. Geological Survey streamgage Clear Fork Mohican River at Bellville, Ohio (station number 03131982)

_ Precipitation (cumulative inches) observed at the Clear Fork Reservoir near Lexington, Ohio, precipitation gage (U.S. Geological Survey station number 03131898)

- Air temperature (hourly) in degrees Fahrenheit, at the Municipal Mansfield Airport, Ohio (station number 14891/MFD)

Figure 1.10. Plot from the U.S. Army Corps of Engineers Hydrologic Engineering Center's Hydrologic Modeling System (HEC-HMS) precipitation-runoff model, run 9, showing simulated and observed streamflows at the U.S. Geological Survey streamgage Clear Fork Mohican River at Bellville, Ohio (station number 03131982); precipitation amounts observed at the USGS precipitation gage at Clear Fork Reservoir near Lexington, Ohio (station number 03131898); and air temperature data observed at the Mansfield Lahm Municipal Airport (NWS station 14891/MFD) during November 5-21, 2017. 
The event on February 25, 2018, resulted in the highest observed peak gage stage of $10.78 \mathrm{ft}(1,120.86 \mathrm{ft}$ NAVD 88$)$ at 07:00 a.m. with an associated streamflow of $4,760 \mathrm{ft}^{3} / \mathrm{s}$ at the Bellville streamgage (USGS, 2018b) (fig. 2, table 6). The HEC-HMS simulation for this event (run 10) commenced on January 27, 2018, and continued through February 27, 2018. The antecedent conditions were saturated, with approximately 1.0 in. of rain on February 19, more rain on February 22 and 24, and unusually warm temperatures ranging from $32^{\circ} \mathrm{F}$ to more than $70^{\circ} \mathrm{F}$ most of the days prior to the peak event. Overall, the simulated results matched well with the observed results, timing and peaks matching well on February 19 and 25 . The simulated peak on February 25 was 30 minutes earlier than the observed peak and the simulated peak streamflow was 9 percent lower than the observed peak streamflow of $4,760 \mathrm{ft}^{3} / \mathrm{s}$. The Nash-Sutcliffe model efficiency coefficient was 0.729 , indicating a good validation run for the model. Figure 1.11 shows the observed (red line) and simulated (blue line) streamflows at the Bellville streamgage (J480, in HEC-HMS) for February 19-26, 2018; the cumulative precipitation in inches (green line) measured at the precipitation gage; and the air temperature data (black line) observed at the NWS station.
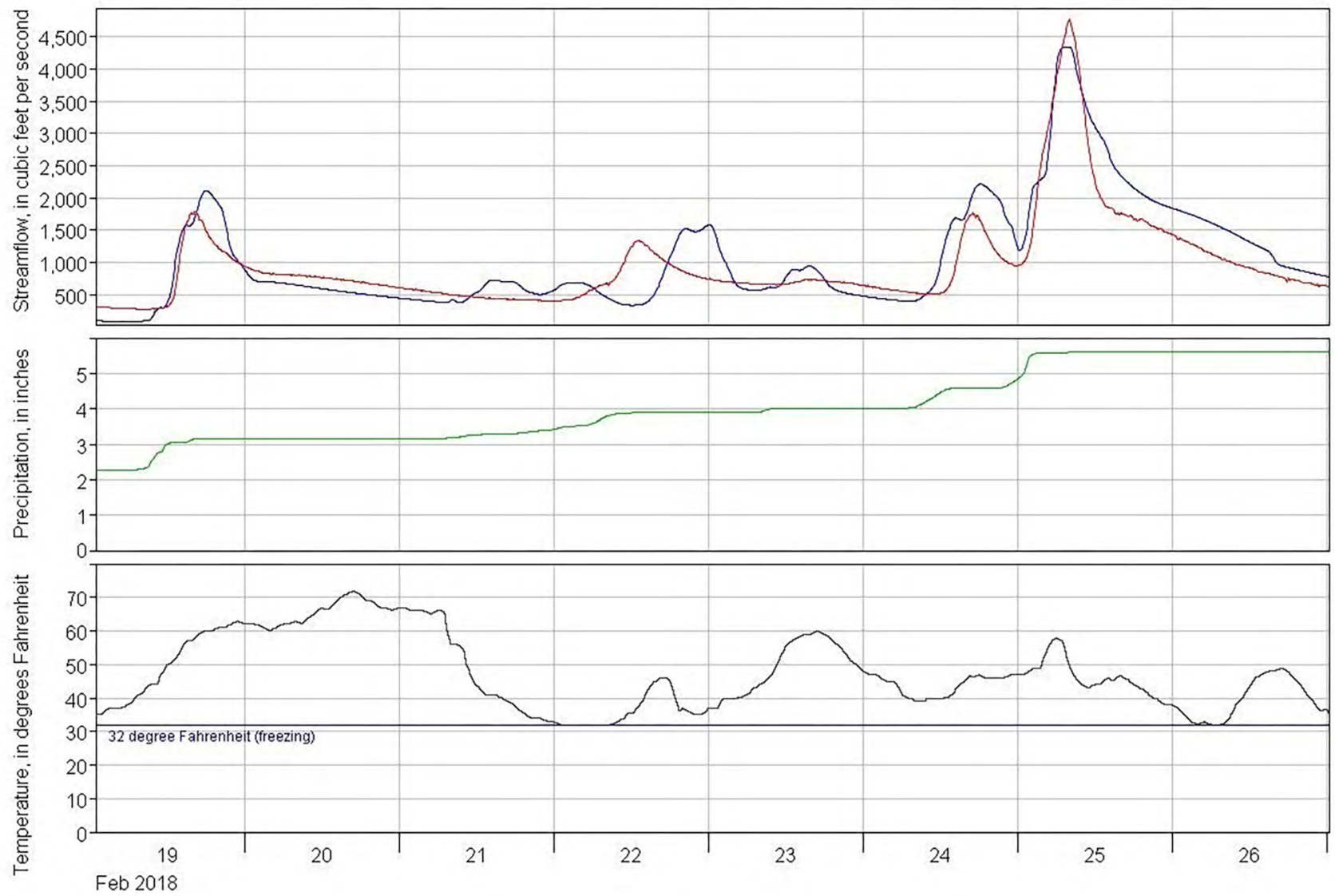

EXPLANATION

— Simulated streamflow from Hydrologic Engineering Center-Hydrologic Modeling System (HEC-HMS) at streamgage location, hydrologic element "J480"'

- Observed streamflow at the U.S. Geological Survey streamgage Clear Fork Mohican River at Bellville, Ohio (station number 03131982)

_ Precipitation (cumulative inches) observed at the Clear Fork Reservoir near Lexington, Ohio, precipitation gage (U.S. Geological Survey station number 03131898) - Air temperature (hourly) in degrees Fahrenheit, at the Municipal Mansfield Airport, Ohio (station number 14891/MFD)

Figure 1.11. Plot from the U.S. Army Corps of Engineers Hydrologic Engineering Center's Hydrologic Modeling System (HECHMS) precipitation-runoff model, run 10, showing simulated and observed streamflows at the U.S. Geological Survey streamgage Clear Fork Mohican River at Bellville, Ohio (station number 03131982); precipitation amounts observed at the USGS precipitation gage at Clear Fork Reservoir near Lexington, Ohio (station number 03131898); and air temperature data observed at the Mansfield Lahm Municipal Airport (NWS station 14891/MFD) during February 19-26, 2018. 


\section{References Cited}

National Oceanic and Atmospheric Administration, 2018, Interactive snow information, MFD-Lahm Municipal Airport: National Operational Hydrologic Remote Sensing Center web page, accessed November 10, 2014, at https:// www.nohrsc.noaa.gov/interactive/html/graph.html?station= $\mathrm{MFD} \& \mathrm{w}=600 \& \mathrm{~h}=400 \& \mathrm{o}=\mathrm{a} \& \mathrm{uc}=0 \& \mathrm{by}=2013 \& \mathrm{bm}=1 \& \mathrm{bd}=$ $3 \& \mathrm{bh}=6 \&$ ey $=2013 \& \mathrm{em}=1 \& \mathrm{ed}=23 \& \mathrm{eh}=6 \&$ data $=0 \&$ units $=0$ \&region=us.
U.S. Army Corps of Engineers (USACE), 2016, Hydrologic modeling system, HEC-HMS, user's manual, version 4.2: Hydrologic Engineering Center Report CPD-74A, 614 p.

U.S. Geological Survey (USGS), 2018b, USGS 03131982 Clear Fork Mohican River at Bellville, Ohio: U.S. Geological Survey National Water Information System, accessed September 20, 2018, at https://waterdata.usgs.gov/ $\mathrm{oh} /$ nwis/inventory/?site_no $=03131982$. 
For more information about this publication, contact Director, Ohio-Kentucky-Indiana Water Science Center U.S. Geological Survey 6460 Busch Boulevard Suite 100

Columbus, $\mathrm{OH}$ 43229-1737

614-430-7700

For additional information visit https://www.usgs.gov/centers/oki-water

Publishing support provided by Madison Publishing Service Center 

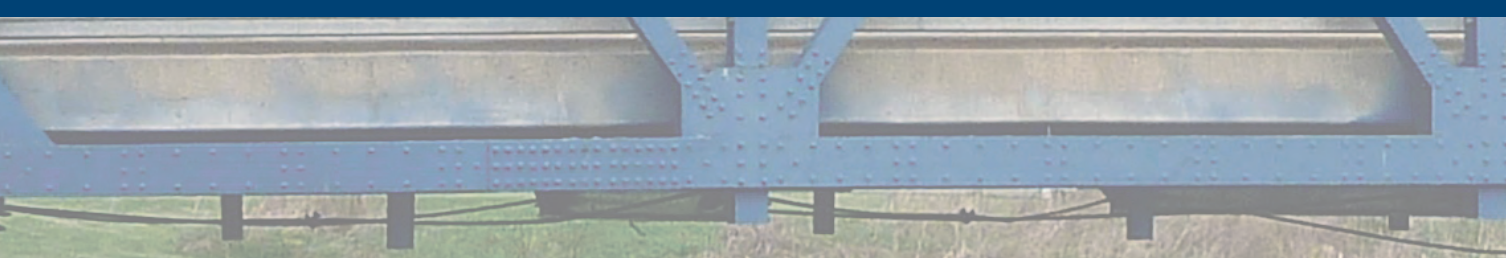

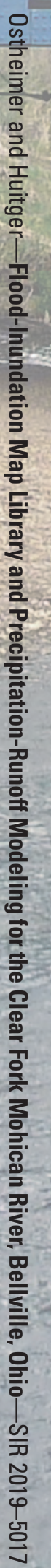

